\title{
Reactions of lithium salts of triphosphines tBu2P-PLi-PtBu 2 and tBu2P-PLi-P(NEt2)2 with metal complexes [(R3P)2MCl2] (M = Ni, Pd, Pt, R3P = Et3P, PTol3P, Ph2EtP, iPr3P)
}

\begin{tabular}{|c|c|}
\hline Journal: & Zeitschrift für Anorganische und Allgemeine Chemie \\
\hline Manuscript ID: & zaac. $200900540 . R 1$ \\
\hline Wiley - Manuscript type: & Article \\
\hline $\begin{array}{r}\text { Date Submitted by the } \\
\text { Author: }\end{array}$ & $10-F e b-2010$ \\
\hline Complete List of Authors: & $\begin{array}{l}\text { Wiśniewska, Aleksandra; Gdańsk University of Technology, Faculty } \\
\text { of Chemistry } \\
\text { Baranowska, Katarzyna; Gdańsk University of Technology, Faculty } \\
\text { of Chemistry } \\
\text { Grubba, Rafał; Gdańsk University of Technology, Faculty of } \\
\text { Chemistry } \\
\text { Matern, Eberhard; Institut für Anorganische Chemie, Universität } \\
\text { Karlsruhe (TH) } \\
\text { Pikies, Jerzy; Gdańsk University of Technology, Faculty of } \\
\text { Chemistry }\end{array}$ \\
\hline Keywords: & P ligands, platinum, nickel, palladium \\
\hline
\end{tabular}

\section{s scholarONE \\ Manuscript Central}




\title{
Reactions of lithium salts of triphosphines ${ }^{t} \mathrm{Bu} \mathbf{u}_{2} \mathbf{P}-\mathbf{P L i}-\mathrm{P}^{t} \mathrm{Bu}_{2}$ and ${ }^{\mathrm{t}} \mathrm{Bu} \mathbf{u}_{2} \mathbf{P}-\mathbf{P L i}-$
} $\mathbf{P}\left(\mathrm{NEt}_{2}\right)_{2}$ with metal complexes $\left[\left(\mathrm{R}_{3} \mathbf{P}\right)_{2} \mathrm{MCl}_{2}\right]\left(\mathrm{M}=\mathrm{Ni}, \mathrm{Pd}, \mathbf{P t}, \mathbf{R}_{3} \mathbf{P}=\mathrm{Et}_{3} \mathbf{P},{ }^{\mathrm{p}} \mathrm{Tol}_{3} \mathrm{P}\right.$, $\left.\mathbf{P h}_{2} \mathbf{E t P},{ }^{\mathrm{i}} \mathbf{P r}_{3} \mathbf{P}\right)$

\author{
Aleksandra Wiśniewska ${ }^{a}$, Katarzyna Baranowska ${ }^{a}$, Rafał Grubba ${ }^{a}$, Eberhard Matern ${ }^{b}$, Jerzy \\ Pikies $^{\mathrm{a}^{*}}$. \\ ${ }^{a}$ Faculty of Chemistry, Department of Inorganic Chemistry, Gdańsk University of Technology, \\ G. Narutowicza St. 11/12. PL-80-233 Gdańsk, Poland \\ ${ }^{\mathrm{b}}$ Institut für Anorganische Chemie, Universität Karlsruhe (TH), Engesserstraße 15, \\ D-76128 Karlsruhe, Germany
}

Received

\footnotetext{
*Prof. Dr. Jerzy Pikies

Faculty of Chemistry,

Department of Inorganic Chemistry,

Gdańsk University of Technology,

G. Narutowicza St. 11/12, PL-80-233 Gdańsk, Poland

e-mail: jerzy.pikies@pg.gda.pl
} 


\begin{abstract}
Bu}_{2} \mathrm{P}-\mathrm{PLi}-\mathrm{P}^{\mathrm{t}} \mathrm{Bu}_{2} \cdot 2 \mathrm{THF}$ reacts with $\left[\left(\mathrm{R}_{3} \mathrm{P}\right)_{2} \mathrm{MCl}_{2}\right](\mathrm{M}=\mathrm{Pt}, \mathrm{Pd}, \mathrm{Ni})$ yielding isomers of $\left[\left(1,2-\eta-{ }^{t} \mathrm{Bu} u_{2} \mathrm{P}=\mathrm{P}-\mathrm{P}^{t} \mathrm{Bu}_{2}\right) \mathrm{M}\left(\mathrm{PR}_{3}\right) \mathrm{Cl}\right]$ where ${ }^{t} \mathrm{Bu} \mathrm{u}_{2} \mathrm{P}-\mathrm{P}-\mathrm{P}^{t} \mathrm{Bu}_{2}$ ligand adopts the geometry of a side-on bonded 1,1-di-tert-butyl-2-(di-tert-butylphosphino)diphosphenium cation. ${ }^{\mathrm{t}} \mathrm{Bu}_{2} \mathrm{P}-\mathrm{PLi}-$ $\mathrm{P}\left(\mathrm{NEt}_{2}\right)_{2} \cdot 2 \mathrm{THF}$ reacts with $\left[\left(\mathrm{R}_{3} \mathrm{P}\right)_{2} \mathrm{MCl}_{2}\right]$ but does not formed complexes with a ${ }^{\mathrm{t}} \mathrm{Bu}_{2} \mathrm{P}-\mathrm{P}-\mathrm{P}(\mathrm{NEt})_{2}$ moiety, however, splitting of a $\mathrm{P}-\mathrm{P}\left(\mathrm{NEt}_{2}\right)_{2}$ bond of the parent triphosphine takes place.
\end{abstract}

Keywords: P ligands; nickel, palladium, platinum. 


\section{Introduction}

Phosphido and phosphinidene complexes of transitions metals are versatile reagents in syntheses of phosphorus - element bond [1].

The reactivity of metal phosphides and silylphosphides towards complexes of nickel triad was studied for three decades. $\mathrm{LiP}\left(\mathrm{SiMe}_{3}\right)_{2}$ reacts with $\left[\mathrm{Cp}(\mathrm{Cl}) \mathrm{Ni}\left(\mathrm{PPh}_{3}\right)\right]$ at low temperature yielding unstable terminal phosphido complex [2], similarly $\left[\left(\mathrm{R}_{3} \mathrm{P}\right)_{2} \mathrm{NiCl}_{2}\right]$ reacts with $\mathrm{LiP}\left(\mathrm{SiMe}_{3}\right)_{2}$ at low temperature yielding unstable mono and diphosphido NI(II) complexes which decompose under formation of cyclic $\mathrm{Ni}(\mathrm{I})$ complexes $\left[\mathrm{R}_{3} \mathrm{P}-\mathrm{Ni}\left\{\mu-\mathrm{P}\left(\mathrm{SiMe}_{3}\right)_{2}\right\}\right]_{2}(\mathrm{Ni}-\mathrm{Ni})$ and side-on bonded diphosphene complexes $\left.\left[\left(\mathrm{R}_{3} \mathrm{P}\right)_{2} \mathrm{Ni}\left(\eta^{2}-\mathrm{Me}_{3} \mathrm{SiP}=\mathrm{PSiMe}\right)_{3}\right)\right][3,4,5,6]$. Similar behaviour was observed in reactions of $\left[(\mathrm{dRpe}) \mathrm{NiCl}_{2}\right]$ with $\mathrm{LiP}\left(\mathrm{SiMe}_{3}\right)_{2}\left(\mathrm{dRpe}=\mathrm{R}_{2} \mathrm{PCH}_{2} \mathrm{CH}_{2} \mathrm{PR}_{2}\right)$, the diphosphorous complexes $\left[\left(\mathrm{R}_{3} \mathrm{P}\right)_{2} \mathrm{Ni}\left(\mu-\mathrm{P}_{2}\right) \mathrm{Ni}\left(\mathrm{PR}_{3}\right)_{2}\right]$ were thereafter isolated.[7,8]. The reactions of $\mathrm{LiP}^{\mathrm{t}} \mathrm{Bu}_{2}$ with $\left[\left(\mathrm{Me}_{3} \mathrm{P}\right)_{2} \mathrm{NiCl}_{2}\right]$ yielded $\left[\mathrm{Me}_{3} \mathrm{P}-\mathrm{Ni}\left\{\mu-\mathrm{P}^{\mathrm{t}} \mathrm{Bu}_{2}\right\}\right]_{2}(\mathrm{Ni}-\mathrm{Ni})$ [9]. Thus, the phosphido ligands tend to occupy bridge positions while the stable Ni-complexes with terminal phosphido groups are rare. Driess et al. reported on the synthesis and X-ray structure of $\left[\mathrm{Cp}\left(\mathrm{Ph}_{3} \mathrm{P}\right) \mathrm{NiPH}\left(\mathrm{SiFTrip}_{2}\right)\right]$ [10] and Hilhouse et al. reported on complex [(dtbpe) $\left.\mathrm{NiP}^{t} \mathrm{Bu}_{2}\right]$ [11] (dtbpe $\left.={ }^{\mathrm{t}} \mathrm{Bu}_{2} \mathrm{PCH}_{2} \mathrm{CH}_{2} \mathrm{P}^{\mathrm{t}} \mathrm{Bu}_{2}\right)$. In both cases the geometry around phosphido $\mathrm{P}$ atoms is pyramidal.

The data on palladium phosphido-complexes are scarce. Reduction of $\left[\right.$ cis- $\left.\left(\mathrm{Cy}_{2} \mathrm{HP}\right)_{2} \mathrm{PdCl}_{2}\right]$ with sodium yields phosphido bridged $\mathrm{Pd}(\mathrm{I})$ complex $\left[\mathrm{Cy}_{2} \mathrm{HPPd}\{\mu-\mathrm{PCy}\}\right]_{2}(P d-P d)[12]$.

$\left[\left(\mathrm{Et}_{3} \mathrm{P}\right)_{2} \mathrm{PdCl}_{2}\right]$ reacts with ${ }^{\mathrm{t}} \mathrm{Bu}_{2} \mathrm{P}-\mathrm{P}=\mathrm{P}^{\mathrm{t}} \mathrm{Bu}_{2}(\mathrm{Me})$ in the presence $\mathrm{Na} / \mathrm{Nph}$ yielding $\left[\mathrm{Et}_{3} \mathrm{PPd}\{\mu\right.$ $\left.\left.\mathrm{P}^{\mathrm{t}} \mathrm{Bu}_{2}\right\}\right]_{2}(P d-P d)[13]$. Terminal phosphido Pd(II) complexes were isolated only for cyclic compounds [(diphos) $\left.\operatorname{Pd}\left\{\left(\mathrm{CH}_{2} \mathrm{C}_{6} \mathrm{H}_{2} \mathrm{Me}_{2}\right) \mathrm{Pd}(\mathrm{Mes})\right\}\right]$ [14].

$\mathrm{LiP}\left(\mathrm{SiMe}_{3}\right)_{2}$ reacts with $\left[\left(\mathrm{R}_{3} \mathrm{P}\right)_{2} \mathrm{PtCl}_{2}\right]$ yielding initially unstable terminal mono and diphosphido $\mathrm{Pt}(\mathrm{II})$ complexes. These complexes decompose at r. t. giving rise to $\operatorname{Pt}(\mathrm{I})$ complexes $\left[\operatorname{Et}_{3} \mathrm{P}-\mathrm{Pt}\{\mu\right.$ $\left.\left.\mathrm{P}\left(\mathrm{SiMe}_{3}\right)_{2}\right\}\right]_{2}(P t-P t)$, side-on bonded diphosphene complexes $\left[\left(\mathrm{Et}_{3} \mathrm{P}\right)_{2} \mathrm{Pt}\left(\eta^{2}-\mathrm{Me}_{3} \mathrm{SiP}=\mathrm{PSiMe} 3\right)\right]$ and diphosphorous complexes $\left[\left(\mathrm{R}_{3} \mathrm{P}\right)_{2} \mathrm{Pt}\left(\mu-\mathrm{P}_{2}\right) \mathrm{Pt}\left(\mathrm{PR}_{3}\right)_{2}\right]$ [15]. The terminal phosphido complexes of $\mathrm{Pt}$ (II) are more stable than related complexes of $\mathrm{Ni}$ and $\mathrm{Pd}$. $\left[\right.$ cis- $\left.\left(\mathrm{PHCy}_{2}\right) \mathrm{PtCl}_{2}\right]$ reacts with sodium at 
r. t. yielding $\left[\mathrm{Cy}_{2} \mathrm{HPPt}\left\{\mu-\mathrm{PCy} y_{2}\right]_{2}(P t-P t)\right.$ and a stable complex $\left[\right.$ trans- $\left.\left(\mathrm{Cy}_{2} \mathrm{HP}\right)_{2} \mathrm{PtCl}(\mathrm{PCy})\right]$. The geometry around terminal phosphido P-atom is pyramidal [16]. A series of stable terminal Pt (II) phosphido complexes [(dppe)Pt(Me)X] $\left(\mathrm{X}=\mathrm{PHR}\right.$ or $\left.\mathrm{PR}_{2}\right)$ was described [17]. For the latest review see [18].

We have studied the reactivity of litiated diphosphines $\mathrm{R}_{2} \mathrm{P}-\mathrm{P}\left(\mathrm{SiMe}_{3}\right) \mathrm{Li}$ and lithiated triphosphine ${ }^{t} \mathrm{Bu}{ }_{2} \mathrm{P}-\mathrm{PLi}-\mathrm{P}^{\mathrm{t}} \mathrm{Bu}_{2}$ towards transition metals complexes. The reaction of $\left[\left(\mathrm{R}_{3} \mathrm{P}\right)_{2} \mathrm{PtCl}_{2}\right]$ with $\mathrm{R}_{2} \mathrm{P}-\mathrm{P}\left(\mathrm{SiMe}_{3}\right)_{2}$ involves mainly a formation of dinuclear diphosphorous complexes $\left[\left(\mathrm{R}_{3} \mathrm{P}\right)_{2} \mathrm{Pt}\left(\mu-\mathrm{P}_{2}\right) \mathrm{Pt}\left(\mathrm{PR}_{3}\right)_{2}\right]$ [19], and, with $\mathrm{R}_{2}^{\prime} \mathrm{P}-\mathrm{P}\left(\mathrm{SiMe}_{3}\right) \mathrm{Li}$ the formation of side-on bonded phosphanylphosphinidene complexes $\left[\left(\eta^{2}-\mathrm{R}_{2}{ }_{2} \mathrm{P}=\mathrm{P}\right) \mathrm{Pt}\left(\mathrm{PR}_{3}\right)_{2}\right]$ but not phosphido complexes. This reaction is relatively general, $\mathrm{R}^{\prime}$ can adopt ${ }^{\mathrm{t}} \mathrm{Bu},{ }^{\mathrm{i}} \mathrm{Pr}, \mathrm{Et}_{2} \mathrm{~N}$ and ${ }^{\mathrm{i}} \mathrm{Pr}_{2} \mathrm{~N}$, but not $\mathrm{Ph}[20]$.

${ }^{\mathrm{t}} \mathrm{Bu}_{2} \mathrm{P}-\mathrm{PLi}-\mathrm{P}^{\mathrm{t}} \mathrm{Bu}_{2} \cdot 2 \mathrm{THF}$ reacts with $\left[\left(\mathrm{Et}_{3} \mathrm{P}\right)_{2} \mathrm{MCl}_{2}\right](\mathrm{M}=\mathrm{Ni}, \mathrm{Pd})$ yielding mixtures of isomers of $\left[\left(1,2-\eta-{ }^{\mathrm{t}} \mathrm{Bu}{ }_{2} \mathrm{P}=\mathrm{P}-\mathrm{P}^{\mathrm{t}} \mathrm{Bu}_{2}\right) \mathrm{M}\left(\mathrm{PEt}_{3}\right) \mathrm{Cl}\right]$. The related reaction with $\left[\right.$ cis- $\left.\left(\mathrm{Et}_{3} \mathrm{P}\right)_{2} \mathrm{PtCl}_{2}\right]$ does not yield $\left[\left(1,2-\eta-{ }^{\mathrm{t}} \mathrm{Bu}{ }_{2} \mathrm{P}=\mathrm{P}-\mathrm{P}^{\mathrm{t}} \mathrm{Bu}_{2}\right) \mathrm{Pt}\left(\mathrm{PEt}_{3}\right) \mathrm{Cl}\right][21]$. Homologous $\left[\left(1,2-\eta-{ }^{\mathrm{t}} \mathrm{Bu}_{2} \mathrm{P}=\mathrm{P}-\mathrm{P}^{\mathrm{t}} \mathrm{Bu}_{2}\right) \mathrm{Pt}\left(\mathrm{PPh}_{3}\right) \mathrm{Br}\right]$ was obtained in a different way and proved to be quite stable [22]. According to the structural and ${ }^{31} \mathrm{P}$ NMR data these complexes can be viewed as a modification of side-on bonded phosphanylphosphinidene complexes rather, than as terminal phosphido complexes [20].

Now we have extended our investigations on the reactivity of ${ }^{t} \mathrm{Bu}_{2} \mathrm{P}-\mathrm{PLi}-\mathrm{P}^{\mathrm{t}} \mathrm{Bu}_{2} \cdot 2 \mathrm{THF}$ with $\left[\left(\mathrm{R}_{3} \mathrm{P}\right)_{2} \mathrm{MCl}_{2}\right](\mathrm{M}=\mathrm{Ni}, \mathrm{Pd}, \mathrm{Pt})$ where $\mathrm{R}$ groups possess different electronic and steric properties. Moreover, we have studied the reactivity of ${ }^{\mathrm{t}} \mathrm{Bu}_{2} \mathrm{P}-\mathrm{PLi}-\mathrm{P}\left(\mathrm{NEt}_{2}\right)_{2} \cdot 2 \mathrm{THF}$ towards $\left[\left(\mathrm{R}_{3} \mathrm{P}\right)_{2} \mathrm{MCl}_{2}\right](\mathrm{M}=$ Ni, Pd, Pt)

\section{Results and Discussion}

\subsection{Reactivity}

The reaction of $\left[\left(\mathrm{R}_{3} \mathrm{P}\right)_{2} \mathrm{MCl}_{2}\right](\mathrm{M}=\mathrm{Pd}, \mathrm{Ni})$ with 1 molar equiv. of ${ }^{\mathrm{t}} \mathrm{Bu}_{2} \mathrm{P}-\mathrm{PLi}-\mathrm{P}^{\mathrm{t}} \mathrm{Bu}_{2} \cdot 2 \mathrm{THF}$ in THF at room temperature yields two isomers of $\left[\left(1,2-\eta-{ }^{\mathrm{t}} \mathrm{Bu}_{2} \mathrm{P}=\mathrm{P}-\mathrm{P}^{\mathrm{t}} \mathrm{Bu} \mathrm{u}_{2}\right) \mathrm{M}\left(\mathrm{PR}{ }_{3}\right) \mathrm{Cl}\right](\mathbf{a}$ and $\mathbf{b})(\mathrm{Scheme} 1)$. 


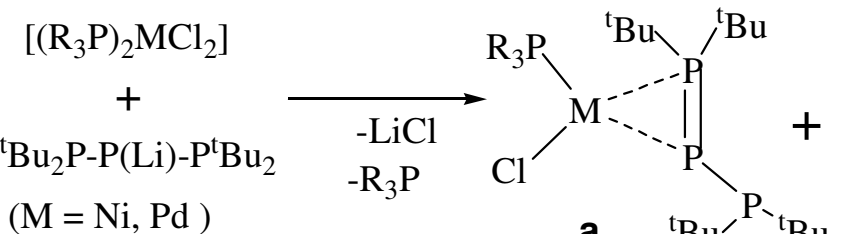<smiles>[R17][Y14]1(Cl)P(P(Br)Br)P1(Br)(Br)Br</smiles>

Scheme 1

However this reaction with platinum complex $\left[\left({ }^{\mathrm{p}} \mathrm{Tol}_{3} \mathrm{P}\right)_{2} \mathrm{PtCl}_{2}\right]$ gave only one isomer $\mathbf{a}$. We have isolated $\left[\left(1,2-\eta-{ }^{\mathrm{t}} \mathrm{Bu}{ }_{2} \mathrm{P}=\mathrm{P}-\mathrm{P}^{\mathrm{t}} \mathrm{Bu}_{2}\right) \mathrm{Pt}\left({ }^{\mathrm{P}} \mathrm{Tol}_{3} \mathrm{P}\right) \mathrm{Cl} \cdot \mathrm{C}_{5} \mathrm{H}_{12}\right](\mathbf{1 a} \cdot$ pentane $),\left[\left(1,2-\eta-{ }^{\mathrm{t}} \mathrm{Bu}_{2} \mathrm{P}=\mathrm{P}-\right.\right.$ $\left.\left.\mathrm{P}^{\mathrm{t}} \mathrm{Bu}_{2}\right) \mathrm{Pd}\left(\mathrm{P}^{\mathrm{P}} \mathrm{Tol}_{3}\right) \mathrm{Cl}\right](\mathbf{2 a}),\left[\left(1,2-\eta-{ }^{\mathrm{t}} \mathrm{Bu}{ }_{2} \mathrm{P}=\mathrm{P}-\mathrm{P}^{\mathrm{t}} \mathrm{Bu}_{2}\right) \mathrm{Pd}\left(\mathrm{P}^{\mathrm{i}} \mathrm{Pr}_{3}\right) \mathrm{Cl}\right](\mathbf{3 b}),\left[\left(1,2-\eta-{ }^{\mathrm{t}} \mathrm{Bu}{ }_{2} \mathrm{P}=\mathrm{P}-\right.\right.$ $\left.\left.\mathrm{P}^{t} \mathrm{Bu}_{2}\right) \mathrm{Ni}\left(\mathrm{PPh}_{2} \mathrm{Et}\right) \mathrm{Cl}\right](\mathbf{4 b})$. We have measured the ratios of isomers $\mathbf{a}$ vs. isomers $\mathbf{b}$ in reactions solutions and after dissolving the isolated isomer in $\mathrm{C}_{6} \mathrm{D}_{6}$ (integrations of $\mathrm{P} 3$ signals in ${ }^{31} \mathrm{P}\left\{{ }^{1} \mathrm{H}\right\}$ NMR spectra) in room temperature. The ratios are similar (see Table 1). However, after repeated crystallisations we have isolated only one isomer. Thus, an equilibrium according to Scheme 2 is very plausible.<smiles>[R19][Y4]1(Cl)P([R7](Br)(Br)CBr)[P+]1(Br)Br</smiles>

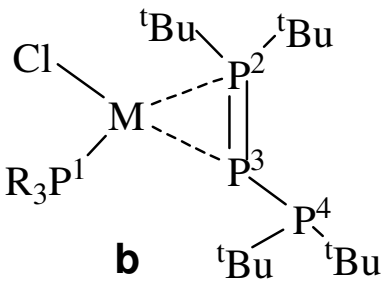

Scheme 2

Table 1. The molar ratio of isomer $\mathbf{a}$ : isomer $\mathbf{b}$ of $\left[\left(1,2-\eta-{ }^{t} \mathrm{Bu}_{2} \mathrm{P}=\mathrm{P}-\mathrm{P}^{\mathrm{t}} \mathrm{Bu} \mathrm{u}_{2}\right) \mathrm{M}\left(\mathrm{PR}_{3}\right) \mathrm{Cl}\right]$ in the reaction solution and in a solution of the isolated complex in $\mathrm{C}_{6} \mathrm{D}_{6}$.

\begin{tabular}{|c|c|c|}
\hline Isolated isomer & $\begin{array}{c}\mathbf{a}: \mathbf{b} \\
\text { reaction sol. }\end{array}$ & $\begin{array}{c}\mathbf{a}: \mathbf{b} \\
\text { dissolved }\end{array}$ \\
\hline$\left[\left(1,2-\eta-{ }^{t} \mathrm{Bu}_{2} \mathrm{P}=\mathrm{P}-\mathrm{P}^{\mathrm{t}} \mathrm{Bu}_{2}\right) \mathrm{Pd}\left(\mathrm{PEt}_{3}\right) \mathrm{Cl}\right] \quad(\mathbf{7 a}) \quad[12]$ & $95: 5$ & $91: 9$ \\
\hline$\left[\left(1,2-\eta-{ }^{t} \mathrm{Bu}{ }_{2} \mathrm{P}=\mathrm{P}-\mathrm{P}^{\mathrm{t}} \mathrm{Bu}_{2}\right) \mathrm{Pd}\left(\mathrm{P}^{\mathrm{p}} \mathrm{Tol}_{3}\right) \mathrm{Cl}\right](\mathbf{2 a})$ & $67: 33$ & $56: 44$ \\
\hline$\left[\left(1,2-\eta-{ }^{t} \mathrm{Bu}_{2} \mathrm{P}=\mathrm{P}-\mathrm{P}^{\mathrm{t}} \mathrm{Bu}_{2}\right) \mathrm{Pd}\left(\mathrm{P}^{\mathrm{i}} \mathrm{Pr}_{3}\right) \mathrm{Cl}\right]$ & $50: 50$ & $44: 56$ \\
\hline$\left[\left(1,2-\eta-{ }^{t} \mathrm{Bu}{ }_{2} \mathrm{P}=\mathrm{P}-\mathrm{P}^{\mathrm{t}} \mathrm{Bu}_{2}\right) \mathrm{Ni}\left(\mathrm{PEt}_{3}\right) \mathrm{Cl}\right] \quad(\mathbf{8 a}) \quad[12]$ & $55: 45$ & $52: 48$ \\
\hline$\left[\left(1,2-\eta-{ }^{t} \mathrm{Bu}_{2} \mathrm{P}=\mathrm{P}-\mathrm{P}^{\mathrm{t}} \mathrm{Bu}_{2}\right) \mathrm{Ni}\left(\mathrm{PPh}_{2} \mathrm{Et}\right) \mathrm{Cl}\right] \quad(\mathbf{4 b})$ & $19: 81$ & $21: 79$ \\
\hline
\end{tabular}


The reaction according to scheme 1 is accompanied by two main side reactions:

i. Exchange of the $\mathrm{R}_{3} \mathrm{P}$ ligand in $\left[\left(1,2-\eta-{ }^{\mathrm{t}} \mathrm{Bu}{ }_{2} \mathrm{P}=\mathrm{P}-\mathrm{P}^{\mathrm{t}} \mathrm{Bu}_{2}\right) \mathrm{M}\left(\mathrm{PR}_{3}\right) \mathrm{Cl}\right]$ with ${ }^{\mathrm{t}} \mathrm{Bu}{ }_{2} \mathrm{PH}$ (Scheme 3$)$.

Thus $\mathbf{2} \mathbf{a}$ and $\mathbf{2 b}$ yield $\mathbf{2} \mathbf{a} *$ and $\mathbf{2} \mathbf{b} *$ (equilibrium), $\mathbf{3 a}$ and $\mathbf{3 b}$ yield $\mathbf{2} \mathbf{a} *$ and $\mathbf{2} \mathbf{b} *$ (equilibrium), $\mathbf{4 b}$ yields $\mathbf{4 b}$ *.<smiles>[R16]N1[Y1]([R16])(Cl)P1(Br)(CBr)CC=C</smiles>

Scheme 3

${ }^{\mathrm{t}} \mathrm{Bu}_{2} \mathrm{PH}$ is a product of a splitting of the $\mathrm{P}-\mathrm{P}$ bond in the triphosphine backbone. Similar splitting was observed and discussed in reactions involving ${ }^{\mathrm{t}} \mathrm{Bu}_{2} \mathrm{P}-\mathrm{P}\left(\mathrm{SiMe}_{3}\right) \mathrm{Li}[19]$.

ii. A reaction leading to formation of a planar isotetraphosphine $\left({ }^{\mathrm{t}} \mathrm{Bu}_{2} \mathrm{P}\right)_{3} \mathrm{P}$ [23]. A mechanism of its formation is not clear. $\left({ }^{\mathrm{t}} \mathrm{Bu}_{2} \mathrm{P}\right)_{3} \mathrm{P}$ was found in many runs.

$\left[\left({ }^{\mathrm{P}} \mathrm{Tol}_{3} \mathrm{P}\right)_{2} \mathrm{PtCl}_{2}\right]$ react with ${ }^{\mathrm{t}} \mathrm{Bu} \mathrm{u}_{2} \mathrm{P}-\mathrm{PLi}-\mathrm{P}^{\mathrm{t}} \mathrm{Bu}_{2} \cdot 2 \mathrm{THF}$ forming $\left[\left(1,2-\eta-{ }^{\mathrm{t}} \mathrm{Bu}{ }_{2} \mathrm{P}=\mathrm{P}-\mathrm{P}^{\mathrm{t}} \mathrm{Bu}_{2}\right) \mathrm{Pt}\left({ }^{\mathrm{P}} \mathrm{Tol}{ }_{3} \mathrm{P}\right) \mathrm{Cl}\right]$

(1a) in a poor yield. In the same experiment we have isolated a phosphanylphosphinidene complex $\left[\left(\eta^{2}-{ }^{\mathrm{t}} \mathrm{Bu}_{2} \mathrm{P}=\mathrm{P}\right) \mathrm{Pt}\left({ }^{\mathrm{P}} \mathrm{Tol}_{3} \mathrm{P}\right)_{2}\right][20]$. In the reaction solution we have detected a significant amount of $\left({ }^{\mathrm{t}} \mathrm{Bu}_{2} \mathrm{P}\right)_{3} \mathrm{P}$ and some amount of a $\mathrm{Pt}$ complex with four $\mathrm{P}$ atoms $(\mathbf{A})$. The formation of $\left({ }^{\mathrm{t}} \mathrm{Bu}{ }_{2} \mathrm{P}\right)_{3} \mathrm{P}$ is not necessary attributed to a formation of $\left[\left(\eta^{2}-{ }^{\mathrm{t}} \mathrm{Bu}_{2} \mathrm{P}=\mathrm{P}\right) \mathrm{Pt}\left({ }^{\mathrm{P}} \mathrm{Tol}_{3} \mathrm{P}\right)_{2}\right]$ since we have not detected this complex in the early stage of run 4.1 .

The reaction of $\left[\left(\mathrm{Et}_{3} \mathrm{P}\right)_{2} \mathrm{PtCl}_{2}\right]$ with ${ }^{\mathrm{t}} \mathrm{Bu}_{2} \mathrm{P}-\mathrm{P}\left(\mathrm{SiMe}_{3}\right)-\mathrm{P}^{\mathrm{t}} \mathrm{Bu}_{2}$ (run 4.2) yields significant amounts of $\left({ }^{\mathrm{t}} \mathrm{Bu}_{2} \mathrm{P}\right)_{3} \mathrm{P}$. However, we have not detected $\left[\left(\eta^{2}-{ }^{\mathrm{t}} \mathrm{Bu}{ }_{2} \mathrm{P}=\mathrm{P}\right) \mathrm{Pt}\left(\mathrm{PEt}_{3}\right)_{2}\right]$ which is fairly stable but then ${ }^{\mathrm{t}} \mathrm{Bu}_{2} \mathrm{P}-\mathrm{P}=\mathrm{PEt}_{3}[24]$. Moreover, $\left({ }^{\mathrm{t}} \mathrm{Bu}_{2} \mathrm{P}\right)_{3} \mathrm{P}$ was isolated in a reaction of $\left[\left(\mathrm{Et}_{2} \mathrm{PhP}\right)_{2} \mathrm{PtCl}_{2}\right]$ with ${ }^{\mathrm{t}} \mathrm{Bu}{ }_{2} \mathrm{P}-$ $\mathrm{PLi}-\mathrm{P}\left(\mathrm{NEt}_{2}\right)_{2} \cdot 2 \mathrm{THF}$.

The known complexes $\left[\left(1,2-\eta-{ }^{\mathrm{t}} \mathrm{Bu}{ }_{2} \mathrm{P}=\mathrm{P}-\mathrm{P}^{\mathrm{t}} \mathrm{Bu}_{2}\right) \mathrm{Pt}\left(\mathrm{PR}_{3}\right) \mathrm{X}\right](\mathrm{X}=\mathrm{Cl}, \mathrm{Br})$ are a-type isomers. This fact can be rationalized, taking into account that trans influence is most important for heaviest 
element in a group [25, 26]. ${ }^{\mathrm{t}} \mathrm{Bu} 2 \mathrm{P} 2$ (scheme 2) exerts stronger trans influence than $\mathrm{P} 3$ (see p. 2.2) and it is advantageous to have $\mathrm{Cl}$ or $\mathrm{Br}$ ligands but not $\mathrm{R}_{3} \mathrm{P} 1$ group trans to $\mathrm{P} 2$ atom

We have studied the reactivity of ${ }^{\mathrm{t}} \mathrm{Bu}{ }_{2} \mathrm{P}-\mathrm{PLi}-\mathrm{P}\left(\mathrm{NEt}_{2}\right)_{2} \cdot 2 \mathrm{THF}$ towards a variety of complexes $\left[\left(\mathrm{R}_{3} \mathrm{P}\right)_{2} \mathrm{MCl}_{2}\right](\mathrm{M}=\mathrm{Pt}, \mathrm{Pd}, \mathrm{Ni})$. To our surprise these compounds do not react under formation of $\left[\left\{1,2-\eta-{ }^{\mathrm{t}} \mathrm{Bu}{ }_{2} \mathrm{P}=\mathrm{P}-\mathrm{P}\left(\mathrm{NEt}_{2}\right)_{2}\right\} \mathrm{M}\left(\mathrm{PR}_{3}\right) \mathrm{Cl}\right]$ or $\left[\left\{1,2-\eta-\left(\mathrm{Et}_{2} \mathrm{~N}\right)_{2} \mathrm{P}=\mathrm{P}-\mathrm{P}^{\mathrm{t}} \mathrm{Bu}_{2}\right) \mathrm{M}\left(\mathrm{PR}_{3}\right) \mathrm{Cl}\right]$. We have isolated and identified only two known compounds and a new adduct of ${ }^{\mathrm{t}} \mathrm{Bu} \mathrm{u}_{2} \mathrm{P}-\mathrm{PLi}-\mathrm{P}\left(\mathrm{NEt}_{2}\right)_{2}$.

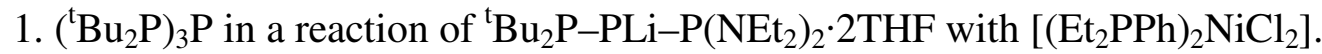

2. $\left[\mu-\left(1,3: 2,3-\eta-{ }^{\mathrm{t}} \mathrm{Bu}_{2} \mathrm{P}_{4}{ }^{\mathrm{t}} \mathrm{Bu}_{2}\right)\left\{\mathrm{Ni}\left(\mathrm{PEt}_{3}\right) \mathrm{Cl}\right\}_{2}\right](\mathbf{5})$ [27] together with two other compounds $\mathbf{B}$ [27] and $\mathrm{C}$ in a reaction of ${ }^{\mathrm{t}} \mathrm{Bu}_{2} \mathrm{P}-\mathrm{PLi}-\mathrm{P}\left(\mathrm{NEt}_{2}\right)_{2} \cdot 2 \mathrm{THF}$ with $\left[\left(\mathrm{Et}_{3} \mathrm{P}\right)_{2} \mathrm{NiCl}_{2}\right]$.

3. ${ }^{\mathrm{t}} \mathrm{Bu}{ }_{2} \mathrm{P}-\mathrm{PLi}-\mathrm{P}\left(\mathrm{NEt}_{2}\right)_{2} \cdot 2 \mathrm{THF}$ react with $\left[\left(\mathrm{Et}_{2} \mathrm{PhP}_{2} \mathrm{PtCl}_{2}\right]\right.$ yielded oily product and $\left({ }^{\mathrm{t}} \mathrm{Bu}_{2} \mathrm{P}\right)_{3} \mathrm{P}$ (not detected in the early stage of this reaction). ${ }^{\mathrm{t}} \mathrm{Bu}{ }_{2} \mathrm{P}-\mathrm{PLi}-\mathrm{P}\left(\mathrm{NEt}_{2}\right)_{2} \cdot 2 \mathrm{THF}$ was converted to relatively inert $\left.\mathrm{LiCl} \cdot 2{ }^{\mathrm{t}} \mathrm{Bu}_{2} \mathrm{P}-\mathrm{PLi}-\mathrm{P}\left(\mathrm{NEt}_{2}\right)_{2}\right\} \cdot 2 \mathrm{THF}$ [28]. This compound does not dissociate into ${ }^{\mathrm{t}} \mathrm{Bu}{ }_{2} \mathrm{P}-\mathrm{PLi}-$ $\mathrm{P}\left(\mathrm{NEt}_{2}\right)_{2}$ in THF solution.

The formation of $\mathbf{5}$ and of $\left({ }^{\mathrm{t}} \mathrm{Bu}_{2} \mathrm{P}\right)_{3} \mathrm{P}$ indicates a splitting of the $\mathrm{P}-\mathrm{P}\left(\mathrm{NEt}_{2}\right)_{2}$ bond in the parent triphosphine backbone.

\section{2. ${ }^{31}$ P-NMR Studies, X-Ray Crystallographic Studies and Discussion}

In Table 2 are collected ${ }^{31} \mathrm{P}\left\{{ }^{1} \mathrm{H}\right\}$ MNR data for complexes with side-on bonded ${ }^{\mathrm{t}} \mathrm{Bu}_{2} \mathrm{P}=\mathrm{P}-\mathrm{P}^{\mathrm{t}} \mathrm{Bu}_{2}$ ligand. These data indicate that the structures in solution are the same as in solid state. The equilibrium according to Scheme 2 is slow in the NMR time scale and we observed separated resonances for all isomers. The large absolute values of the couplings constants ${ }^{1} \mathrm{~J}_{\mathrm{P} 2-\mathrm{P} 3}$ of 560/518 $\mathrm{Hz}(\mathrm{M}=\mathrm{Pd}, \mathrm{Ni})$ and $482 / 447(\mathrm{M}=\mathrm{Pt})$ show that this bond has a multiple bond character. Noteworthy is a substantial high field shift of P3 (-66 / -130 ppm) indicating a single-bond character of a Pt-P3 bond. Similar features displays side-on bonded ${ }^{\mathrm{t}} \mathrm{Bu}(\mathrm{Cl}) \mathrm{P}=\mathrm{P}-{ }^{\mathrm{t}} \mathrm{Bu}$ connected to $\mathrm{CpW}(\mathrm{CO})_{2}$ centre [29]. The values of trans $^{2} \mathrm{JP1} 1 \mathrm{P} 2$ in "b" complexes are in the range 249.9/270 $\mathrm{Hz}(\mathrm{M}=\mathrm{Pd})$ and $178.3 / 194.3 \mathrm{~Hz}(\mathrm{M}=\mathrm{Ni})$. In "a" complexes the values of trans $^{2} \mathrm{JP1}$-P3 are in the 
range $102.9 / 108.5 \mathrm{~Hz}(\mathrm{M}=\mathrm{Pt}, \mathrm{Pd})$ and $75.6 / 75.8(\mathrm{M}=\mathrm{Ni})$. Thus the trans influence of $\mathrm{P} 2$ is stronger than that of P3. This assumption is additionally supported by the values of ${ }^{1} \mathrm{JPt}-\mathrm{P}$ in $\mathbf{1 a}$. The ${ }^{1} \mathrm{JPt}-\mathrm{P} 1$ trans to $\mathrm{P} 3$ is $3437.3 \mathrm{~Hz}$ and is similar to the ${ }^{1} \mathrm{JPt}-\mathrm{P}$ coupling in [cis-( $\left.{ }^{\mathrm{P}} \mathrm{Tol} 3 \mathrm{P}\right) 2 \mathrm{PtCl}$ ] of $3627 \mathrm{~Hz}$. Thus according to the criterion of Benett [30] P3 atom exerts very low trans influence, similar to that of a $\mathrm{Cl}$ atom.

Table 2. $\quad{ }^{31} \mathrm{P}\left\{{ }^{1} \mathrm{H}\right) \mathrm{NM}\left(\mathrm{R}\right.$ data for $\left[\left(1,2-\eta-{ }^{\mathrm{t}} \mathrm{Bu}{ }_{2} \mathrm{P}=\mathrm{P}-\mathrm{P}^{\mathrm{t}} \mathrm{Bu}_{2}\right) \mathrm{M}\left(\mathrm{PR}_{3}\right) \mathrm{Cl}\right](\mathrm{M}=\mathrm{Ni}, \mathrm{Pd})$

\begin{tabular}{|c|c|c|c|c|c|c|c|c|c|c|c|c|}
\hline & $\mathrm{M}$ & $\mathrm{R}_{3} \mathrm{P} 1$ & $\begin{array}{l}\delta \mathrm{P} 1 \\
\mathrm{ppm}\end{array}$ & $\begin{array}{l}\delta \mathrm{P} 2 \\
\mathrm{ppm}\end{array}$ & $\begin{array}{l}\delta \mathrm{P} 3 \\
\mathrm{ppm}\end{array}$ & $\begin{array}{l}\delta \mathrm{P} 4 \\
\mathrm{ppm}\end{array}$ & $\begin{array}{c}\mathbf{J}_{\mathrm{P} 1-\mathrm{P} 2} \\
\mathrm{~Hz}\end{array}$ & $\begin{array}{c}\mathrm{J}_{\mathrm{P} 1-\mathrm{P} 3} \\
\mathrm{~Hz}\end{array}$ & $\begin{array}{c}\mathrm{J}_{\mathrm{P} 1-\mathrm{P} 4} \\
\mathrm{~Hz}\end{array}$ & $\begin{array}{c}\mathrm{J}_{\mathrm{P} 2-\mathrm{P} 3} \\
\mathrm{~Hz} \\
\end{array}$ & $\begin{array}{c}\mathrm{J}_{\mathrm{P} 2-\mathrm{P} 4} \\
\mathrm{~Hz}\end{array}$ & $\begin{array}{c}\mathrm{J}_{\mathrm{P} 3-\mathrm{P} 4} \\
\mathrm{~Hz}\end{array}$ \\
\hline $1 a$ & $\mathrm{Pt}$ & ${ }^{\mathrm{P}} \mathrm{Tol}_{3} \mathrm{P}$ & 26.2 & 62.4 & -130.4 & 27.8 & 20.7 & 107.8 & \multirow{10}{*}{2.2} & 447.3 & 32.6 & 254.7 \\
\hline $6 \mathrm{a}^{\mathrm{a}}$ & $\mathrm{Pt}$ & $\mathrm{Ph}_{3} \mathrm{P}$ & 28.0 & 61.0 & -125.9 & 32.0 & 22.0 & 107.0 & & 482.0 & 34.0 & 251.0 \\
\hline $\mathbf{2 a}$ & $\mathrm{Pd}$ & ${ }^{\mathrm{p}} \mathrm{Tol}_{3} \mathrm{P}$ & 20.1 & 105.5 & -87.7 & 28.7 & 25.2 & 103.3 & & 549.7 & 33.2 & 246.7 \\
\hline $2 b$ & $\mathrm{Pd}$ & ${ }^{\mathrm{p}} \mathrm{Tol}_{3} \mathrm{P}$ & 15.9 & 97.2 & -65.7 & 33.3 & 265.1 & 13.8 & & 539.2 & 36.7 & 247.8 \\
\hline $2 a^{*}$ & $\mathrm{Pd}$ & ${ }^{t} \mathrm{Bu}_{2} \mathrm{H}$ & 30.7 & 104.2 & -89.7 & 26.8 & 25.5 & 104.1 & & 557.6 & 32.1 & 248.9 \\
\hline $2 b^{*}$ & $\mathrm{Pd}$ & ${ }^{\mathrm{t}} \mathrm{Bu}_{2} \mathrm{H}$ & $41.8^{\mathrm{b}}$ & 75.6 & -66.2 & 26.9 & 251.2 & 16.1 & & 547.3 & 32.1 & 242.1 \\
\hline $3 \mathbf{a}$ & $\mathrm{Pd}$ & ${ }^{\mathrm{i}} \mathrm{Pr}_{3} \mathrm{P}$ & 47.7 & 100.8 & -88.4 & 31.0 & 23.0 & 102.9 & & 551.7 & 30.3 & 255.2 \\
\hline $3 b$ & $\mathrm{Pd}$ & ${ }^{\mathrm{i}} \mathrm{Pr}_{3} \mathrm{P}$ & 35.5 & 77.2 & -74.8 & 32.5 & 249.9 & 16.2 & & 535.8 & 30.3 & 255.1 \\
\hline $7 \mathbf{a}^{\mathrm{c}}$ & $\mathrm{Pd}$ & $\mathrm{Et}_{3} \mathrm{P}$ & 22.6 & 110.3 & -103.4 & 26.2 & 21.7 & 108.5 & & 550.8 & 33.5 & 248.0 \\
\hline $7 b^{c}$ & $\mathrm{Pd}$ & $\mathrm{Et}_{3} \mathrm{P}$ & 10.7 & 79.2 & -74.5 & 28.8 & 270.0 & 15.3 & & 534.0 & 34.9 & 241.0 \\
\hline $4 a$ & $\mathrm{Ni}$ & $\mathrm{Ph}_{2} \mathrm{Et}$ & 21.4 & 69.9 & -119.2 & 32.7 & 30.2 & 75.8 & \multirow{5}{*}{2.2} & 531.6 & 25.5 & 257.0 \\
\hline $4 b$ & $\mathrm{Ni}$ & $\mathrm{Ph}_{2} \mathrm{Et}$ & 13.6 & 39.5 & -97.5 & 36.4 & 191.0 & $\approx 0$ & & 523.5 & 29.4 & 253.6 \\
\hline $4 b^{*}$ & $\mathrm{Ni}$ & ${ }^{\mathrm{t}} \mathrm{Bu}_{2} \mathrm{H}$ & 40.4 & 22.9 & -90.6 & 32.0 & 178.3 & $\approx 0$ & & 538.5 & 22.3 & 255.1 \\
\hline $8 a^{c}$ & $\mathrm{Ni}$ & $\mathrm{Et}_{3} \mathrm{P}$ & 19.9 & 72.8 & -127.8 & 31.8 & 33.4 & 75.6 & & 531.6 & 26.4 & 256.3 \\
\hline $8 b^{d, c}$ & $\mathrm{Ni}$ & $\mathrm{Et}_{3} \mathrm{P}$ & 7.1 & 31.3 & -101.8 & 34.1 & 194.3 & 2.4 & & 518.0 & 27.8 & 252.8 \\
\hline
\end{tabular}

The structures of 1a·pentane (Fig. 1), 2a (Fig. 2), 3b (Fig. 3) and 4b (Fig. 4) were determined by X-ray diffraction methods $[31,32]$. The crystal data, details of the data collection and refinement are given in Table 3.

The Pt atom in 1a (RMS deviations of fitted atoms $=1.69 \mathrm{pm})$ and the Pd atom in $\mathbf{2 a}(\mathrm{RMS}$ deviations $=1.10 \mathrm{pm}$ ) are in an almost planar environment defined by $\mathrm{R}_{3} \mathrm{P} 1, \mathrm{Cl}$ and the $\mathrm{P} 2-\mathrm{P} 3$ bond. In $3 \mathbf{b}(\mathrm{RMS}$ deviations $=5.46 \mathrm{pm})$ the environment around Pd atom displays small deviations from planarity and in $\mathbf{4 b}(\mathrm{RMS}$ deviations $=23.7 \mathrm{pm})$ the environment around $\mathrm{Ni}$ atom displays substantial deviations from planarity. The P2-P3 distances are short: 214.50(2) pm in 1a, 
1

2

3

4

5

6

7

8
213.03(13) pm in 2a, 213.32(7) pm in $\mathbf{3 b}$ and 212.54 (12) pm in $\mathbf{4 b}$. These data and literature data for $\mathbf{6 a}-214.9(2) \mathrm{pm} \mathrm{[22],} \mathrm{for} \mathrm{7a-213.68(5)} \mathrm{pm} \mathrm{[21]} \mathrm{and} \mathrm{for} \mathrm{8a-212.81(10)} \mathrm{pm} \mathrm{[21]} \mathrm{indicate}$ general trend that the distances P2-P3 diminish in the order Pt $>\mathrm{Pd}>\mathrm{Ni}$. These short distances are typical for the double $\mathrm{P}=\mathrm{P}$ bond of diphosphenes upon $\eta^{2}$-coordination [33]. All P3-P4 distances are in the range of single $\mathrm{P}-\mathrm{P}$ bonds [34].

Table 3. Summary of crystallographic data and structure refinement details for $\mathbf{1 a - 4 b .}$ 


\begin{tabular}{|c|c|c|c|c|}
\hline & $1 \mathrm{a}$ & $2 a$ & $3 \mathbf{b}$ & $4 b$ \\
\hline Empirical formula & $\mathrm{C}_{42} \mathrm{H}_{69} \mathrm{ClP}_{4} \mathrm{Pt}$ & $\mathrm{C}_{37} \mathrm{H}_{57} \mathrm{ClP}_{4} \mathrm{Pd}$ & $\mathrm{C}_{25} \mathrm{H}_{57} \mathrm{ClP}_{4} \mathrm{Pd}$ & $\mathrm{C}_{30} \mathrm{H}_{51} \mathrm{ClP}_{4} \mathrm{Ni}$ \\
\hline$M_{\mathrm{r}} / \mathrm{g} \mathrm{mol}^{-1}$ & 928.39 & 767.56 & 623.44 & 629.75 \\
\hline Temperature /K & $120(2)$ & $120(2)$ & $120(2)$ & $120(2)$ \\
\hline Wavelength / & $0.71073\left(\mathrm{Mo} \mathrm{K}_{\alpha}\right)$ & $0.71073\left(\mathrm{Mo} \mathrm{K}_{\alpha}\right)$ & $0.71073\left(\mathrm{Mo} \mathrm{K}_{\alpha}\right)$ & $0.71073\left(\mathrm{Mo} \mathrm{K}_{\alpha}\right)$ \\
\hline Crystal system & monoclinic & triclinic & triclinic & monoclinic \\
\hline Space group & $P 2_{1} / c$ & $P-1$ & $P-1$ & $P 2_{1} / \mathrm{c}$ \\
\hline$a / \AA$ & $14.7717(4)$ & $11.9728(5)$ & $8.4306(4)$ & $8.2709(4)$ \\
\hline$b / \AA$ & $24.5098(6)$ & $12.7680(5)$ & $11.8235(4)$ & $19.6137(12)$ \\
\hline$c / \AA$ & $13.2810(3)$ & $14.2078(9)$ & $16.9039(6)$ & $20.2758(12)$ \\
\hline$\alpha /^{\circ}$ & 90 & $93.391(4)$ & $89.747(3)$ & 90 \\
\hline$\beta 1^{\circ}$ & $110.902(2)$ & $114.571(4)$ & $91.967(3)$ & $93.444(4)$ \\
\hline$\gamma /{ }^{\circ}$ & 90 & $98.813(3)$ & $108.684(4)$ & 90 \\
\hline$V / \AA^{3}$ & $4491.97(19)$ & 1933.61(17) & $1595.19(10)$ & $3283.3(3)$ \\
\hline $\mathrm{Z}$ & 4 & 2 & 2 & 4 \\
\hline Calc. density $/ \mathrm{Mg} \mathrm{m}^{-3}$ & 1.373 & 1.318 & 1.298 & 1.274 \\
\hline Crystal size / mm & $0.26 \times 0.24 \times 0.15$ & $0.08 \times 0.06 \times 0.02$ & $0.16 \times 0.09 \times 0.02$ & $0.10 \times 0.05 \times 0.02$ \\
\hline$\theta$ range $1^{\circ}$ & 1.96 to 25.5 & 1.91 to 25.5 & 2.17 to 25.5 & 2.26 to 25.5 \\
\hline \multirow[t]{3}{*}{ Limiting indices } & $-17<=\mathrm{h}<=17$ & $-13<=\mathrm{h}<=14$ & $-10<=\mathrm{h}<=10$ & $-10<=\mathrm{h}<=10$ \\
\hline & $-27<=\mathrm{k}<=29$ & $-15<=k<=15$ & $-14<=\mathrm{k}<=13$ & $-23<=\mathrm{k}<=21$ \\
\hline & $-16<=1<=16$ & $-16<=1<=17$ & $-20<=1<=20$ & $-24<=1<=24$ \\
\hline Reflections collected / & 31323 / 8354 & 14073 / 7206 & $11626 / 5947$ & 23453 / 6098 \\
\hline unique & {$[R(\mathrm{int})=0.0565]$} & {$[R(\mathrm{int})=0.0394]$} & {$[R(\mathrm{int})=0.0226]$} & {$[R(\mathrm{int})=0.0706]$} \\
\hline Completeness to & 100 & 99.8 & 99.8 & 100 \\
\hline \multicolumn{5}{|l|}{$\theta_{\max } 1 \%$} \\
\hline \multicolumn{5}{|l|}{$/ \mathrm{mm}^{-1}$} \\
\hline $\begin{array}{l}\text { Data / restraints / } \\
\text { parameters }\end{array}$ & $8354 / 0 / 450$ & $7206 / 0$ / 403 & 5947 / 0 / 298 & 6098 / 0 / 338 \\
\hline Goodness-of-fit on $F^{2}$ & 1.16 & 1.041 & 1.151 & 0.932 \\
\hline \multirow[t]{2}{*}{ Final $R$ indices $[I>2 \sigma(I)]$} & $R 1=0.0501$ & $R 1=0.0379$ & $R 1=0.0253$ & $R 1=0.0412$ \\
\hline & $w R 2=0.1228$ & $w R 2=0.0949$ & $w R 2=0.0645$ & $w R 2=0.0917$ \\
\hline \multirow[t]{2}{*}{$R$ indices (all data) } & $R 1=0.0712$ & $R 1=0.0543$ & $R 1=0.0308$ & $R 1=0.0737$ \\
\hline & $w R 2=0.1393$ & $w R 2=0.1077$ & $w R 2=0.067$ & $w R 2=0.0978$ \\
\hline Largest diff. peak and & 1.576 and & 0.703 and & 0.588 and & 0.559 and \\
\hline hole $/ \mathrm{e} \AA^{-3}$ & -1.146 & -0.67 & -0.627 & -0.607 \\
\hline
\end{tabular}


The M-P distances display distinct differences depending on the isomer type. In $\mathbf{3 b}$ the Pd-P1 distance 234.32 (9) pm, trans to P2 is longer than 236.03 pm reported for Pd-P bond in [trans$\left.\left({ }^{\mathrm{i}} \mathrm{Pr}_{3} \mathrm{P}\right)_{2} \mathrm{PdCl}_{2}\right][35]$. Thus ${ }^{\mathrm{t}} \mathrm{Bu}_{2} \mathrm{P} 2$ exerts strong trans influence. $\mathrm{Pd}-\mathrm{P} 2$ bond is very short 225.39(15) pm, similarly to 225.8 (3) reported for $\mathrm{Pd}-\mathrm{P}$ bond in [cis-( $\left.\left.\mathrm{Me}_{3} \mathrm{P}\right)_{2} \mathrm{PdCl}_{2}\right]$ [36], however, it has ${ }^{\mathrm{i}} \mathrm{Pr}_{3} \mathrm{P} 1$ in trans position. The $\mathrm{Pd}-\mathrm{P} 3$ bond of $238.59(5)$ pm trans to $\mathrm{Cl}$ atom is a long one. In 2a Pd-P1 (234.32 (9) pm) is shorter than in 3b (238.77(5) pm)- but Pd-P3 bond of 241.79 (9) pm, trans to ${ }^{\mathrm{P}} \mathrm{Tol}_{3} \mathrm{P}$ is a very long one. Thus, $\mathrm{P} 3$ exerts small trans influence but the $\mathrm{Pd}-\mathrm{P} 3$ bond lengthens very significantly if a tertiary phosphine is in trans position to it. The same was observed in $\mathrm{Ni}$ complexes $\mathbf{4 b}$ and $\mathbf{8 a}$.

FIGURE 1. An ORTEP view of the molecular structure of 1a in the crystal; hydrogen atoms not shown, ellipsoids are drawn at 30\% probability level. Selected bond lengths $[\mathrm{pm}]$ and angles $\left[^{\circ}\right]$ : Pt1-Cl1 236.37(15); Pt1-P1 228.53(17); Pt1-P2 221.24(16); Pt1-P3 240.77(18); P2-P3 214.50(2); P3-P4 221.80(3); P2-Pt1-P3 55.14(6); P2-P3-P4 106.92(10).

FIGURE 2. An ORTEP view of the molecular structure of 2a in the crystal; hydrogen atoms not shown, ellipsoids are drawn at $30 \%$ probability level. Selected bond lengths [pm] and angles $\left[{ }^{\circ}\right]$ : Pd1-Cl1 238.62(9); Pd1-P1 234.32(9); Pd1-P2 223.15(9); Pd1-P3 241.79(9); P2-P3 213.03(13); P3P4 222.40(13); P2-Pd1-P3 67.28(4); P2-P3-P4 106.78(5).

FIGURE 3. An ORTEP view of the molecular structure of $\mathbf{3 b}$ in the crystal; hydrogen atoms not shown, ellipsoids are drawn at $30 \%$ probability level. Selected bond lengths [pm] and angles $\left[{ }^{\circ}\right]$ : Pd1-Cl1 237.63(5); Pd1-P1 238.77(5); Pd1-P2 225.39(5); Pd1-P3 238.59(5); P2-P3 213.32(7); P3P4 224.05(7); P2-Pd1-P3 54.654(17); P2-P3-P4 102.96(3).

FIGURE 4. An ORTEP view of the molecular structure of $\mathbf{4 b}$ in the crystal; hydrogen atoms not shown, ellipsoids are drawn at 30\% probability level. Selected bond lengths [pm] and angles [ ${ }^{\circ}$ ]: Ni1-Cl1 220.46(9); Ni1-P1 223.68(10); Ni1-P2 214.83(10); Ni1-P3 226.05(10); P2-P3 212.54(12); P3-P4 224.80(12); P2-Ni1-P3 57.58(3); P2-P3-P4 105.58(5). 
In 1a the Pt-P2, Pt-P3 and Pt-Cl distances are very similar to those reported in $\mathbf{2 a}(\mathrm{M}=\mathrm{Pd})$, however the Pt-P1 distance of 228.53 (7) pm is shorter than Pd-P1 distance in 2a. We have suggested [21] two Lewis structures which partially explain properties of this class of complexes. The features of X-ray structures are well explained by the Lewis structure 1 (Scheme 4) .
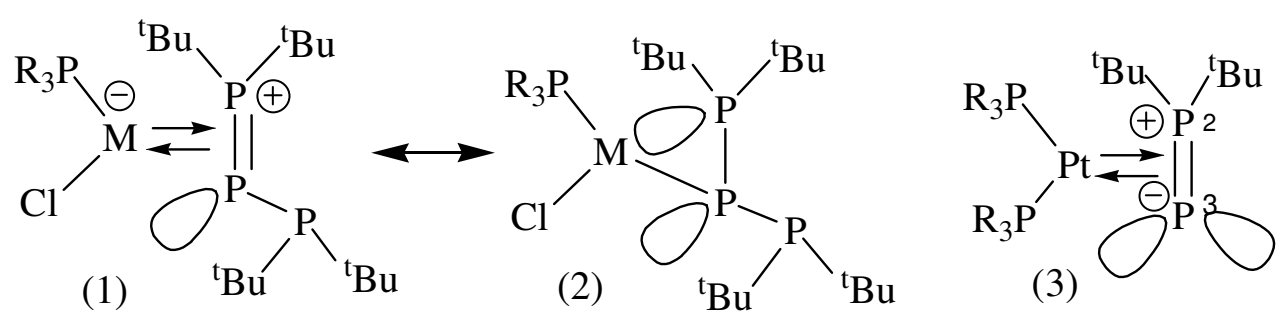

Scheme 4

The planar alignments around the metal centres in all this compounds are in accord with assumption that $\left(\mathrm{R}_{3} \mathrm{P}\right) \mathrm{ClM}^{-}$groups exhibit properties of $\mathrm{a} \mathrm{d}^{10} \mathrm{ML}_{2}$ metal centre [37] and so this ligand can be seen as an $\eta^{2}$ bonded 1,1-di-tert-butyl-2-(di-tert-butylphosphanylo)diphosphenium cation. Related phosphanylophosphenium cation has a planar geometry [38]. The short distances $\mathrm{M}-\mathrm{P}^{\mathrm{t}} \mathrm{Bu}_{2}(\mathrm{Scheme}$ 4, structure 1) are due to additional electrostatic interactions. Such interactions are not possible in side-on bonded phosphanylphosphinidene platinum complexes (Scheme 4, structure 3). Thus the $\mathrm{Pt}-\mathrm{P}^{\mathrm{t}} \mathrm{Bu}_{2}$ distance in $\left[\left({ }^{\mathrm{P}} \mathrm{Tol}_{3} \mathrm{P}\right)_{2} \mathrm{Pt}\left(\eta^{2}{ }^{\mathrm{t}} \mathrm{Bu}_{2} \mathrm{P}=\mathrm{P}\right)\right]$ is $230.59(17) \mathrm{pm}[20]$ compared to $\mathrm{Pt}-\mathrm{P} 2$ in $\mathbf{1 a}$ 221.24 (16) pm. This distance is shorter than $\mathrm{Pt}-\mathrm{P}^{\mathrm{t}} \mathrm{Bu}_{2} \mathrm{H}$ distance in $\left[\right.$ cis- $\left.\left(\mathrm{Ph}_{3} \mathrm{P}\right)\left({ }^{\mathrm{t}} \mathrm{Bu}_{2} \mathrm{PH}\right) \mathrm{PtCl}_{2}\right]$ (225.3 pm) [39]. These additional electrostatic interactions may be partially responsible for a greater value of ${ }^{1} \mathrm{~J}_{\mathrm{Pt}-\mathrm{P} 2}$ in $\mathbf{1 a}$ compared to $\left[\left({ }^{\mathrm{P}} \mathrm{Tol}_{3} \mathrm{P}\right)_{2} \mathrm{Pt}\left(\eta^{2}-{ }^{\mathrm{t}} \mathrm{Bu}{ }_{2} \mathrm{P}=\mathrm{P}\right)\right][20]$. The geometry around $\mathrm{P} 3$ atom differs to some extent from the geometry of side-on bonded diphosphenes. The P4-P3-P2 angle in $\mathbf{1 a}$ of $106.71 \mathrm{deg}$ differs slightly from the related angle in $\left[\left(\eta^{2}-{ }^{\mathrm{t}} \mathrm{Bu} \mathrm{u}_{2} \mathrm{P}-\mathrm{P}=\mathrm{P}-\mathrm{P}^{\mathrm{t}} \mathrm{Bu}_{2}\right) \mathrm{Pt}\left(\mathrm{PPh}_{3}\right)_{2}\right]$ - 111.12 deg. The torsion angle Pt-P2-P3-P4 of 107.12 deg differs from the related value in $\left[\left(\eta^{2}-\right.\right.$ $\left.\left.{ }^{\mathrm{t}} \mathrm{Bu}_{2} \mathrm{P}-\mathrm{P}=\mathrm{P}-\mathrm{P}^{\mathrm{t}} \mathrm{Bu}_{2}\right) \mathrm{Pt}\left(\mathrm{PPh}_{3}\right)_{2}\right]-103.82 \mathrm{deg}[33]$. The sum of angles around ${ }^{\mathrm{p}} \mathrm{Tol}_{3} \mathbf{P 1}$ in $\mathbf{1 a}$ is 312.67 deg. The sum of angles around ${ }^{\mathrm{t}} \mathrm{Bu}_{2} \mathbf{P 2}-\mathrm{P}$ is $344.62 \mathrm{deg}$. Thus the geometry around $\mathrm{P} 2$ atom is more planar than around P1 atom. The Lewis structure 2 (Scheme 4) explains the relatively large ${ }^{1} \mathrm{~J}_{\mathrm{Pt}-\mathrm{P} 2}$ 
(2776.8 Hz for $\mathbf{1 a}$ and $2740 \mathrm{~Hz}$ for $\mathbf{6 a})$. These values of ${ }^{1} \mathrm{~J}_{\mathrm{Pt}-\mathrm{P} 3}$ of $187.0 \mathrm{~Hz}^{1}$ (6a) and $188.1 \mathrm{~Hz}(\mathbf{1 a})$ are however smaller than reported for ${ }^{t} \mathrm{Bu}_{2} \mathrm{P}-\mathrm{P}=\mathrm{P}-\mathrm{P}^{\mathrm{t}} \mathrm{Bu} \mathrm{u}_{2}$ bonded side-on to $\mathrm{d}^{10} \mathrm{PtL}_{2}$ centre (332 / $404 \mathrm{~Hz}$ ) [33] and significantly smaller than in terminal phosphido complexes with tertiary phosphine in trans position $(573 \mathrm{~Hz} / 675$ [15], 806 / $1239 \mathrm{~Hz}$ [17]) but greater than in complexes with ${ }^{\mathrm{t}} \mathrm{Bu}_{2} \mathrm{P}=\mathrm{P}$ bonded side-on to $\mathrm{d}^{10} \mathrm{PtL}_{2}$ centre (32 / $104 \mathrm{~Hz}$ ) [40]. The planar geometry of P1-ClP2-P3-M in Lewis structure 2 (Scheme 4) is obvious in terms of the planarity of low spin $\mathrm{d}^{8} \mathrm{ML}_{2}$ complexes.

The crystallographic data have been deposited in the Cambridge Crystallographic Data Centre as supplementary publications CCDC 746220 (1a·pentane), CCDC 746221 (2a), CCDC 746222 (3b) and CCDC 746223 (4b). Copies of the data can be obtained free of charge on application to the Director CCDC, 12 Union Road, Cambridge CB21EZ, UK (fax: +(44) 1223-336-033; e-mail for inquiring: fileserv@ccdc.cam.ac.uk,e-mail for deposition: deposit@ccdc.cam.ac.uk

\section{Conclusion}

We have isolated several new complexes $\left[\left(1,2-\eta-{ }^{t} \mathrm{Bu}_{2} \mathrm{P}=\mathrm{P}-\mathrm{P}^{\mathrm{t}} \mathrm{Bu} \mathrm{u}_{2}\right) \mathrm{M}\left(\mathrm{PR}_{3}\right) \mathrm{Cl}\right]$ which are products of reactions of $\left[\left(\mathrm{R}_{3} \mathrm{P}\right)_{2} \mathrm{MCl}_{2}\right]$ with ${ }^{t} \mathrm{Bu}_{2} \mathrm{P}-\mathrm{PLi}-\mathrm{P}^{\mathrm{t}} \mathrm{Bu}_{2}$. In solution we observed a mixture of isomers in an equilibrium. For $\left[\left({ }^{\mathrm{P}} \mathrm{Tol}_{3} \mathrm{P}\right)_{2} \mathrm{PtCl}_{2}\right]$ only one isomer of $\left[\left(1,2-\eta-{ }^{\mathrm{t}} \mathrm{Bu}_{2} \mathrm{P}=\mathrm{P}-\mathrm{P}^{\mathrm{t}} \mathrm{Bu}_{2}\right) \mathrm{Pt}\left(\mathrm{PR}_{3}\right) \mathrm{Cl}\right]$ was formed together with a phosphanylophosphinidene complex $\left[\left(\eta^{2}-{ }^{\mathrm{t}} \mathrm{Bu}_{2} \mathrm{P}=\mathrm{P}\right) \mathrm{Pt}\left(\mathrm{P}^{\mathrm{p}} \mathrm{Tol}_{32}\right)_{2}\right]$. The studied reactions are not general for lithiated triphosphines and were successful only for a compound with voluminous ${ }^{\mathrm{t}} \mathrm{Bu}$ groups. Surprisingly ${ }^{\mathrm{t}} \mathrm{Bu}{ }_{2} \mathrm{P}-\mathrm{PLi}-\mathrm{P}\left(\mathrm{N}^{\mathrm{i}} \mathrm{Pr}_{2}\right)_{2}$ does not form related complexes with 1,2- $-{ }^{\mathrm{t}} \mathrm{Bu}_{2} \mathrm{P}=\mathrm{P}-\mathrm{P}\left(\mathrm{N}^{\mathrm{i}} \mathrm{Pr}_{2}\right)_{2}$ or $2,3-\eta-{ }^{\mathrm{t}} \mathrm{Bu}{ }_{2} \mathrm{P}-\mathrm{P}=\mathrm{P}\left(\mathrm{N}^{\mathrm{i}} \mathrm{Pr}_{2}\right)_{2}$ ligands but a splitting of a $\mathrm{P}-\mathrm{P}\left(\mathrm{N}^{\mathrm{i}} \mathrm{Pr}_{2}\right)_{2}$ was observed. It seems reasonable to study related reactions involving lithiated triphospines with smaller groups e. i. ${ }^{\mathrm{i}} \mathrm{Pr}_{2} \mathrm{P}-\mathrm{PLi}-\mathrm{P}^{\mathrm{i}} \mathrm{Pr}_{2}$.

\footnotetext{
${ }^{1}$ The value $95 \mathrm{~Hz}$ previously reported [21, 22] was a mistake.
} 


\section{Experimental}

All manipulations were performed in flame-dried Schlenk type glassware on a vacuum line. THF and toluene were dried over $\mathrm{Na} /$ benzophenone and distilled under nitrogen. Pentane was dried over $\mathrm{Na} /$ benzophenone/diglyme and distilled under nitrogen. ${ }^{31} \mathrm{P}$ NMR spectra were recorded on Bruker Av400 and on Bruker AMX300 spectrometers (external standard $85 \% \mathrm{H}_{3} \mathrm{PO}_{4}$ ) at ambient temperature. The ${ }^{1} \mathrm{H}$ NMR signals for $\mathbf{2 a}, \mathbf{2} \mathbf{b}$ and $\mathbf{3 b}$ were established from ${ }^{31} \mathrm{P}-{ }^{1} \mathrm{H}-\mathrm{COSY}$ spectra. ${ }^{t} \mathrm{Bu}{ }_{2} \mathrm{P}-\mathrm{P}\left(\mathrm{SiMe}_{3}\right)-\mathrm{P}^{t} \mathrm{Bu}_{2}$ was prepared in a one-pot reaction [41] and lithiated according to literature procedures [42], ${ }^{\mathrm{t}} \mathrm{Bu}_{2} \mathrm{P}-\mathrm{PLi}-\mathrm{P}\left(\mathrm{NEt}_{2}\right)_{2}$ was prepared according to literature procedures [43]

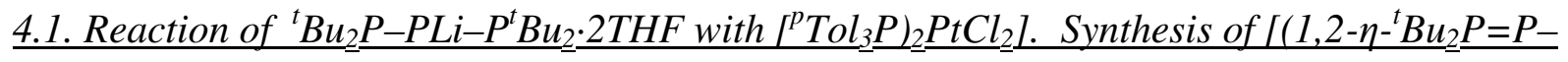 $\left.\underline{P^{t} B u_{2}} \underline{P t}\left(p-\operatorname{Tol}_{3} \underline{P}\right) C l\right](\mathbf{l a})$.}

A solution of ${ }^{t} \mathrm{Bu}_{2} \mathrm{P}-\mathrm{PLi}-\mathrm{P}^{\mathrm{t}} \mathrm{Bu}_{2} \cdot 2 \mathrm{THF}(0.187 \mathrm{~g}, 0.396 \mathrm{mmol})$ in THF $(2 \mathrm{~mL})$ was added at room temperature to a suspension of $\left[\right.$ cis/trans $\left.-\left({ }^{p} \mathrm{Tol}_{3} \mathrm{P}\right)_{2} \mathrm{PtCl}_{2}\right](0.346 \mathrm{~g}, 0.396 \mathrm{mmol})$ in THF $(2 \mathrm{~mL})$. The mixture was stirred for $1 \mathrm{~d}$, the suspension dissolved (the solution turned orange) and was investigated with ${ }^{31} \mathrm{P}\left\{{ }^{1} \mathrm{H}\right\} \mathrm{NMR}$, then evacuated at $2 \cdot 10^{-3}$ Torr for $2 \mathrm{~h}$. The residue was dissolved in toluene $(4 \mathrm{~mL})$ and filtered. The volume was reduced to $\approx 1 \mathrm{~mL}$ and pentane $(4 \mathrm{~mL})$ was carefully layered over the toluene solution. After 7 days at $+4{ }^{\circ} \mathrm{C}$ orange crystals of 1a·pentane deposited $(0.079 \mathrm{~g}, 21 \%$ yield $)$. Then the mother liquor was separated from crystals and after 7 days at + $4{ }^{\circ} \mathrm{C}$ yielded small amount of red crystals of $\left[\left(\eta^{2}-{ }^{\mathrm{t}} \mathrm{Bu}{ }_{2} \mathrm{P}=\mathrm{P}\right) \mathrm{Pt}\left(\mathrm{p}-\mathrm{Tol}_{3} \mathrm{P}\right)_{2}\right][20]$

${ }^{31} \mathrm{P}-\mathrm{NMR}$ examination of reaction solution: $\mathbf{1 a},\left({ }^{\mathrm{t}} \mathrm{Bu}_{2} \mathrm{P}\right){ }_{3} \mathrm{P}[23],\left[\right.$ cis- $\left.\left(p-\mathrm{Tol}_{3} \mathrm{P}\right)\left({ }^{\mathrm{t}} \mathrm{Bu}_{2} \mathrm{PH}\right) \mathrm{PtCl}_{2}\right]$, ${ }^{\mathrm{t}} \mathrm{Bu}_{2} \mathrm{P}-\mathrm{PH}-\mathrm{P}^{\mathrm{t}} \mathrm{Bu}_{2}[41], p-\mathrm{Tol}_{3} \mathrm{P}, \mathrm{A}$.

1a : ${ }^{31} \mathrm{P}\left\{{ }^{1} \mathrm{H}\right\} \operatorname{NMR}\left(161.94 \mathrm{MHz}, \mathrm{MHz}, \mathrm{C}_{6} \mathrm{D}_{6}\right.$, THF, $25{ }^{\circ} \mathrm{C}$, $) \delta=26.2(\mathrm{dd}, \mathrm{P} 1) ; 62.4$ (ddd, P2);130.4 (ddd, P3); 27.8 (dd, P4); ${ }^{1} \mathrm{~J}_{\mathrm{Pt}-\mathrm{P} 1}=3437.3 \mathrm{~Hz},{ }^{1} \mathrm{~J}_{\mathrm{Pt}-\mathrm{P} 2}=2776.8 \mathrm{~Hz},{ }^{1} \mathrm{~J}_{\mathrm{Pt}-\mathrm{P} 3}=188.1 \mathrm{~Hz},{ }^{1} \mathrm{~J}_{\mathrm{Pt}-\mathrm{P} 4}=$ $45.9 \mathrm{~Hz},{ }^{2} \mathrm{~J}_{\mathrm{P} 1-\mathrm{P} 2}=20.7 \mathrm{~Hz},{ }^{2} \mathbf{J}_{\mathrm{P} 1-\mathrm{P} 3}=107.8 \mathrm{~Hz},{ }^{3} \mathrm{~J}_{\mathrm{P} 1-\mathrm{P} 4} \approx 0 \mathrm{~Hz},{ }^{1} \mathrm{~J}_{\mathrm{P} 2-\mathrm{P} 3}=-447.3 \mathrm{~Hz},{ }^{2} \mathbf{J}_{\mathrm{P} 2-\mathrm{P} 4}=32.6 \mathrm{~Hz}$, ${ }^{1} \mathrm{~J}_{\mathrm{P} 3-\mathrm{P} 4}=-254.7 \mathrm{~Hz}$. 


\subsection{Reaction of $\left.\left.{ }^{t} \mathrm{~B} \underline{u}_{2} \underline{P-P\left(\operatorname{SiMe}_{3}\right)-P^{t} B u_{2}} \underline{\text { with }\left[\left(E t_{3}\right.\right.} \underline{P}\right)_{2} \underline{P t C l} \underline{P}_{2}\right]$.}

A solution of ${ }^{t} \mathrm{Bu}_{2} \mathrm{P}-\mathrm{P}\left(\mathrm{SiMe}_{3}\right)-\mathrm{P}^{\mathrm{t}} \mathrm{Bu}_{2}(0.11 \mathrm{~g}, 0.28 \mathrm{mmol})$ in $\mathrm{THF}(2 \mathrm{~mL})$ was added at room temperature to a solution of $\left[\right.$ cis/trans $\left.-\left(\mathrm{Et}_{3} \mathrm{P}\right)_{2} \mathrm{PtCl}_{2}\right](0.14 \mathrm{~g}, 0.28 \mathrm{mmol})$ in $\mathrm{THF}(7 \mathrm{~mL})$. The mixture turned slowly yellow. After $1 \mathrm{~d}$ the solution was concentrated to $2 \mathrm{~mL}$ and colourless crystals of $\left({ }^{\mathrm{t}} \mathrm{Bu}_{2} \mathrm{P}\right)_{3} \mathrm{P}$ deposited.

${ }^{31} \mathrm{P}-\mathrm{NMR}$ examination of reaction solution $\left(101.26 \mathrm{MHz}, \mathrm{C}_{6} \mathrm{D}_{6}\right.$, THF, $\left.25^{\circ} \mathrm{C}\right):\left({ }^{\mathrm{t}} \mathrm{Bu}_{2} \mathrm{P}\right)_{3} \mathrm{P}[23]$, [cis$\left.\left(\mathrm{Et}_{3} \mathrm{P}\right)\left({ }^{\mathrm{t}} \mathrm{Bu}_{2} \mathrm{PH}\right) \mathrm{PtCl}_{2}\right],{ }^{\mathrm{t}} \mathrm{Bu}_{2} \mathrm{PH}, p-\mathrm{Tol}_{3} \mathrm{P},\left[\right.$ cis- $\left.\left(\mathrm{Et}_{3} \mathrm{P}\right)_{2} \mathrm{PtCl}_{2}\right],\left[\right.$ trans $\left.-\left(\mathrm{Et}_{3} \mathrm{P}\right)_{2} \mathrm{PtCl}_{2}\right],{ }^{\mathrm{t}} \mathrm{Bu}_{2} \mathrm{P}-\mathrm{P}=\mathrm{PEt}_{3}$ [24] $\left[\right.$ cis- $\left.\left(\mathrm{Et}_{3} \mathrm{P} 2\right)\left({ }^{\mathrm{t}} \mathrm{Bu}_{2} \mathrm{P} 1 \mathrm{H}\right) \mathrm{PtCl}_{2}\right]{ }^{31} \mathrm{P}\left\{{ }^{1} \mathrm{H}\right\}$ NMR $\left(101.26 \mathrm{MHz}, \mathrm{C}_{6} \mathrm{D}_{6}, \mathrm{THF}, 25{ }^{\circ} \mathrm{C},\right) \delta=34.4(\mathrm{~d}, \mathrm{P} 1) ; 4.7$ $\operatorname{ppm}(\mathrm{d}, \mathrm{P} 2) ;{ }^{1} \mathrm{~J}_{\mathrm{Pt}-\mathrm{P} 1}=3531.0 \mathrm{~Hz},{ }^{1} \mathrm{~J}_{\mathrm{Pt}-\mathrm{P} 2}=3365.8 \mathrm{~Hz},{ }^{2} \mathrm{~J}_{\mathrm{P} 1-\mathrm{P} 2}=15.4 \mathrm{~Hz}$,

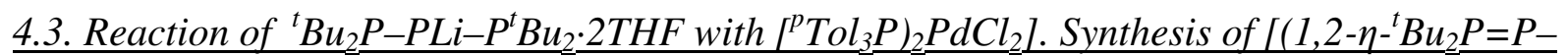

\section{$\left.\left.\underline{P^{t} B u_{2}} \underline{2}\right) P d\left(P^{p} \operatorname{Tol}_{3}\right) C l\right](2 a)$.}

A solution of ${ }^{t} \mathrm{Bu}_{2} \mathrm{P}-\mathrm{PLi}-\mathrm{P}^{\mathrm{t}} \mathrm{Bu}_{2} \cdot 2 \mathrm{THF}(0.210 \mathrm{~g}, 0.444 \mathrm{mmol})$ in THF $(2 \mathrm{~mL})$ was added at room temperature to a suspension of $\left[\left({ }^{\mathrm{P}} \mathrm{Tol}_{3} \mathrm{P}\right)_{2} \mathrm{PdCl}_{2}\right](0.349 \mathrm{~g}, 0.444 \mathrm{mmol})$ in THF $(2 \mathrm{~mL})$. The yellow suspension turned immediately dark red. After stirring for $2 \mathrm{~h}$ the suspension dissolved and volume was reduced to $2 \mathrm{~mL}$. The reaction mixture was investigated by ${ }^{31} \mathrm{P}\left\{{ }^{1} \mathrm{H}\right\} \mathrm{NMR}$. Then the solution was evaporated to dryness under vacuum, dissolved in toluene (4 mL) filtrated, concentrated to 1 $\mathrm{mL}$ and stored for $5 \mathrm{~d}$ at $4{ }^{\circ} \mathrm{C}$. Crystals of ${ }^{\mathrm{p}} \mathrm{Tol}_{3} \mathrm{P}$ were deposited. Then the solution was stored for 
$14 \mathrm{~d}$ at $-35^{\circ} \mathrm{C}$. The pale yellow crystals of $\left({ }^{\mathrm{t}} \mathrm{Bu}_{2} \mathrm{P}\right)_{3} \mathrm{P}$ were deposited. The resulting mother liquor was layered with pentane. After $14 \mathrm{~d}$ at $4{ }^{\circ} \mathrm{C}$ orange needles of $2 \mathbf{a}$ deposited $(0.106 \mathrm{~g}, 31 \%$ yield).

${ }^{31} \mathbf{P}-\mathbf{M N R}$ examination of reaction solution. $\mathbf{2 a}, \mathbf{2 b}, \mathbf{2} \mathbf{a} *$ (small signals), $\mathbf{2} \mathbf{b} *$ (small signals), ${ }^{\mathrm{t}} \mathrm{Bu}_{2} \mathrm{P}-$ $\mathrm{PH}-\mathrm{P}^{\mathrm{t}} \mathrm{Bu}_{2}$ (small signals) and $\left({ }^{\mathrm{t}} \mathrm{Bu} \mathrm{H}_{2} \mathrm{P}\right)_{3} \mathrm{P}$ (small signals).

2a : ${ }^{1} \mathrm{H}$ NMR $\left(400.13 \mathrm{MHz}, \mathrm{C}_{6} \mathrm{D}_{6}, 25^{\circ} \mathrm{C}\right): \delta=7.91\left(\mathrm{~m}, o-\mathrm{H}\right.$ of $\mathrm{C}_{7} \mathrm{H}_{7} \mathrm{P} 1$ of $\mathbf{2 a}$ or $\mathbf{2 b} ; 6.94(\mathrm{~m}$, probably $m-\mathrm{H}$ of $\mathrm{C}_{7} \mathrm{H}_{7} \mathrm{P} 1$ of $\mathbf{2 a}$ or $\mathbf{2 b}$, overlap with $\left.p-\mathrm{Tol}_{3} \mathrm{P}\right) ; 2.003\left(\mathrm{~s}, \mathrm{CH}_{3}\right.$ of $p-\mathrm{Tol}_{3} \mathrm{P} 1$ of $\mathbf{2 a}$ or 2b); $1.991\left(\mathrm{~s}, \mathrm{CH}_{3}\right.$ of $p$-Tol ${ }_{3} \mathrm{P} 1$ of $\mathbf{2 a}$ or $\left.\mathbf{2 b}\right) ; 1.902\left(\mathrm{~d}, 11.9 \mathrm{~Hz}, \mathbf{H}_{3} \mathrm{CCP} 4\right) ; 1.386(\mathrm{~d}, 10.7 \mathrm{~Hz}$, $\left.\mathbf{H}_{3} \mathrm{CCP} 4\right) ; 1.282$ (d, 16.6 Hz, $\left.\mathbf{H}_{3} \mathrm{CCP} 2\right) ; 1.148$ (d, $\left.15.2 \mathrm{~Hz}, \mathbf{H}_{3} \mathrm{CCP} 2\right)$;

2b : ${ }^{1} \mathrm{H}$ NMR $\left(400.13 \mathrm{MHz}, \mathrm{C}_{6} \mathrm{D}_{6}, 25{ }^{\circ} \mathrm{C}\right):$ ) : $\delta=7.91\left(\mathrm{~m}, o-\mathrm{H}\right.$ of $\mathrm{C}_{7} \mathrm{H}_{7} \mathrm{P} 1$ of $\mathbf{2 a}$ or $\mathbf{2 b} ; 6.94(\mathrm{~m}$, probably $m-\mathrm{H}$ of $\mathrm{C}_{7} \mathrm{H}_{7} \mathrm{P} 1$ of $\mathbf{2 a}$ or $\mathbf{2 b}$, overlap with $\left.p-\mathrm{Tol}_{3} \mathrm{P}\right) ; 2.003\left(\mathrm{~s}, \mathrm{CH}_{3}\right.$ of $p-\mathrm{Tol}_{3} \mathrm{P} 1$ of $\mathbf{2 a}$ or 2b); $1.991\left(\mathrm{~s}, \mathrm{CH}_{3}\right.$ of $p$-Tol ${ }_{3} \mathrm{P} 1$ of $\mathbf{2 a}$ or $\left.\mathbf{2 b}\right) ; 1.829\left(\mathrm{~d}, 17.1 \mathrm{~Hz}, \mathbf{H}_{3} \mathrm{CCP} 2\right) ; 1.508(\mathrm{~d}, 13.8 \mathrm{~Hz}$, $\left.\mathbf{H}_{3} \mathrm{CCP} 2\right) ; 1.464$ (d, $\left.10.7 \mathrm{~Hz}, \mathbf{H}_{3} \mathrm{CCP} 4\right) ; 1.082\left(\mathrm{~d}, 11.5 \mathrm{~Hz}, \mathbf{H}_{3} \mathrm{CCP} 4\right)$;

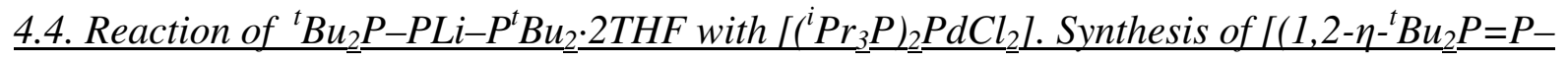 $\underline{P^{t} B u_{2}} \underline{2} \underline{P d}\left(P^{i} \operatorname{Pr}_{3} \underline{L} \underline{C l l(3 \boldsymbol{b})}\right.$.}

A solution of ${ }^{\mathrm{t}} \mathrm{Bu}_{2} \mathrm{P}-\mathrm{PLi}-\mathrm{P}^{\mathrm{t}} \mathrm{Bu}_{2} \cdot 2 \mathrm{THF}(0.208 \mathrm{~g}, 0.440 \mathrm{mmol})$ in THF $(3 \mathrm{~mL})$ was added at room temperature to a suspension of $\left[\left({ }^{\mathrm{i}} \mathrm{Pr}_{3} \mathrm{P}\right)_{2} \mathrm{PdCl}_{2}\right](0.219 \mathrm{~g}, 0.440 \mathrm{mmol})$ in $\mathrm{THF}(2 \mathrm{~mL})$. The yellow solution turned orange-brown. After stirring for $1 \mathrm{~h}$ the suspension dissolved volume was reduced to $2 \mathrm{~mL}$ and investigated by ${ }^{31} \mathrm{P}\left\{{ }^{1} \mathrm{H}\right\}$ NMR. Then the solution was evaporated to dryness under vacuum, dissolved in toluene (4 $\mathrm{mL})$ filtrated and concentrated to $1 \mathrm{ml}$. The solution was layered with pentane $(4 \mathrm{~mL})$ and stored for $7 \mathrm{~d}$ at $4{ }^{\circ} \mathrm{C}$. Orange crystals deposited: $\mathbf{3 b}(0.160 \mathrm{~g}, 58 \%$ yield $)$. ${ }^{31} \mathbf{P}-\mathbf{M N R}$ examination of reaction solution: $\mathbf{3 a}, \mathbf{3 b}, \mathbf{2} \mathbf{a}^{*}, \mathbf{2} \mathbf{b}^{*},{ }^{\mathrm{t}} \mathrm{Bu}{ }_{2} \mathrm{P}-\mathrm{PH}-\mathrm{P}^{\mathrm{t}} \mathrm{Bu}_{2},{ }^{\mathrm{t}} \mathrm{Bu}_{2} \mathrm{PH}$ and $\left[\left({ }^{\mathrm{i}} \mathrm{Pr}_{3} \mathrm{P}\right)_{2} \mathrm{PdCl}_{2}\right]$ were found.

3a: ${ }^{1} \mathrm{H}$ NMR (400.13 MHz, $\left.\mathrm{C}_{6} \mathrm{D}_{6}, 25^{\circ} \mathrm{C}\right): 1.773\left(\mathrm{~d}, 12.0 \mathrm{~Hz}, \mathbf{H}_{3} \mathrm{CCP} 4\right) ; 1.576(\mathrm{dd}, 1.1 \mathrm{~Hz}+16.0$ $\left.\mathrm{Hz}, \mathbf{H}_{3} \mathrm{CCP} 2\right) ; 1.453$ (d, $\left.10.5 \mathrm{~Hz}, \mathbf{H}_{3} \mathrm{CCP} 4\right)$; Others signals we were not able to assign unequivocally to $\mathrm{H}$ atoms of $\mathbf{3 a}$. 
3b: ${ }^{1} \mathrm{H}$ NMR (400.13 MHz, $\left.\mathrm{C}_{6} \mathrm{D}_{6}, 25^{\circ} \mathrm{C}\right): 1.389$ (d, $\left.11.0 \mathrm{~Hz}, \mathbf{H}_{3} \mathrm{CCP} 4\right)$; Others signals we were not able to assign unequivocally to $\mathrm{H}$ atoms of $\mathbf{3 b}$.

\subsection{Reaction of ${ }^{t} B u_{2} \underline{P-P L i-P^{t} B u_{2}} \underline{2} \underline{2 T H F}$ with $\left[\left(P h_{2} \underline{E t P}\right)_{2} \underline{N i C l_{2}}\right]$. Synthesis of $\left[\left(1,2-\eta{ }^{t} B u_{2} \underline{P}=P-\right.\right.$ $\underline{P^{t} B u_{2}} \underline{L} \underline{N i\left(P P h_{2}\right.} \underline{E t) C l\rceil(4 \boldsymbol{b})}$.}

A solution of ${ }^{\mathrm{t}} \mathrm{Bu}_{2} \mathrm{P}-\mathrm{PLi}-\mathrm{P}^{\mathrm{t}} \mathrm{Bu}_{2} \cdot 2 \mathrm{THF}(0.210 \mathrm{~g}, 0.444 \mathrm{mmol})$ in THF $(2 \mathrm{~mL})$ was added at room temperature to a suspension of $\left[\left(\mathrm{Ph}_{2} \mathrm{EtP}_{2} \mathrm{NiCl}_{2}\right](0.248 \mathrm{~g}, 0.444 \mathrm{mmol})\right.$ in THF $(2 \mathrm{~mL})$. The cherry-red solution turned red-brown and the suspension dissolved. Then the solution was evaporated to dryness under vacuum, dissolved in toluene $(4 \mathrm{~mL})$ filtrated and concentrated to $1 \mathrm{ml}$. Pentane $(4 \mathrm{~mL})$ was put over the toluene solution and the bulb was stored for $5 \mathrm{~d}$ at $4{ }^{\circ} \mathrm{C}$. Cherry-red crystals deposited: $4 \mathbf{b},(0.212 \mathrm{~g}, 76 \%$ yield $)$

${ }^{31} \mathbf{P}-\mathrm{MNR}$ examination of reaction solution: $\mathbf{4 a}, \mathbf{4 b},\left[\left(1,2-\eta-{ }^{t} \mathrm{Bu}{ }_{2} \mathrm{P}=\mathrm{P}-\mathrm{P}^{\mathrm{t}} \mathrm{Bu} \mathrm{u}_{2}\right) \mathrm{Ni}\left(\mathrm{P}^{\mathrm{t}} \mathrm{Bu} \mathrm{u}_{2} \mathrm{H}\right) \mathrm{Cl}\right](\mathbf{4} \mathbf{b} *)$, ${ }^{\mathrm{t}} \mathrm{Bu} \mathrm{u}_{2} \mathrm{P}-\mathrm{PH}-\mathrm{P}^{\mathrm{t}} \mathrm{Bu}_{2},{ }^{\mathrm{t}} \mathrm{Bu}_{2} \mathrm{PH},{ }^{\mathrm{t}} \mathrm{Bu} \mathrm{u}_{2} \mathrm{PCl}$ and $\mathrm{Ph}_{2} \mathrm{EtP}$ were found.

\subsection{Reaction of ${ }^{t} \mathrm{Bu}_{2} \underline{P}-\mathrm{PLi}-\mathrm{P}\left(\mathrm{NEt_{2 }} \underline{2}_{2} \cdot 2 \mathrm{2THF}\right.$ with $\left.\left[\left(\mathrm{Et}_{3} \underline{\underline{P}}\right)_{2}\right)_{2} \mathrm{NiCl}_{2}\right]$. Synthesis of $[\mu-(1,3: 2,3-\eta-$}

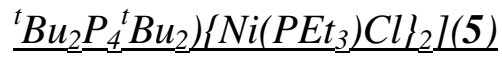

A solution of ${ }^{\mathrm{t}} \mathrm{Bu}_{2} \mathrm{P}-\mathrm{PLi}-\mathrm{P}\left(\mathrm{NEt}_{2}\right)_{2} \cdot 2 \mathrm{THF}(0.271 \mathrm{~g}, 0.539 \mathrm{mmol})$ in THF $(2 \mathrm{~mL})$ was added at room temperature to a suspension of $\left[\left(\mathrm{Et}_{3} \mathrm{P}\right)_{2} \mathrm{NiCl}_{2}\right](0.193 \mathrm{~g}, 0.527 \mathrm{mmol})$ in THF $(2 \mathrm{~mL})$. The cherryred solution turned red-brown and the suspension dissolved. Then the solution was evaporated to dryness under vacuum, dissolved in toluene $(4 \mathrm{~mL})$ filtrated and concentrated to $1 \mathrm{ml}$. Pentane $(5 \mathrm{~mL})$ was put over the toluene solution and the bulb was stored for one week at $-35^{\circ} \mathrm{C}$. Small amount of cherry-red crystals of $\mathbf{5}$ was deposited (0.049g).

${ }^{31} \mathbf{P}-\mathrm{MNR}$ examination of reaction solution: 5 [18], $\mathbf{B}[18], \mathbf{C},\left(\mathrm{Et}_{2} \mathrm{~N}\right)_{3} \mathrm{P},{ }^{\mathrm{t}} \mathrm{Bu}_{2} \mathrm{PH},{ }^{\mathrm{t}} \mathrm{Bu}_{2} \mathrm{P}-\mathrm{P}=\mathrm{PEt}_{3}$ and $\mathrm{Et}_{3} \mathrm{P}$ were found.

$5:{ }^{31} \mathrm{P}\left\{{ }^{1} \mathrm{H}\right\}$ NMR (101.26 MHz, Tol, $\left.\mathrm{C}_{6} \mathrm{D}_{6}, 25{ }^{\circ} \mathrm{C},\right) \delta=-28.5$ (dddd, P1); -1.0 (dddd, P2), -94.6 (ddddd, P3), 70.6 (m, P4), 5.0 (ddd, P5), 8.6 (m, P6), J $\mathrm{J}_{\mathrm{P} 1-\mathrm{P} 2}=197.8, \mathrm{~J}_{\mathrm{P} 1-\mathrm{P} 3}=89.2, \mathrm{~J}_{\mathrm{P} 1-\mathrm{P} 4}=$ 
$10.5, \mathrm{~J}_{\mathrm{P} 1-\mathrm{P} 5}=292.2, \mathrm{~J}_{\mathrm{P} 1-\mathrm{P} 6}=2.2, \mathrm{~J}_{\mathrm{P} 2-\mathrm{P} 3}=298.5, \mathrm{~J}_{\mathrm{P} 2-\mathrm{P} 4}=11.8, \mathrm{~J}_{\mathrm{P} 2-\mathrm{P} 5}=1.9, \mathrm{~J}_{\mathrm{P} 3-\mathrm{P} 4}=511.3$, $\mathrm{J}_{\mathrm{P} 3-\mathrm{P} 5}=64.8, \mathrm{~J}_{\mathrm{P} 3-\mathrm{P} 6}=187.5, \mathrm{~J}_{\mathrm{P} 4-\mathrm{P} 5}=2.5, \mathrm{~J}_{\mathrm{P} 4-\mathrm{P} 6}=8.0, \mathrm{~J}_{\mathrm{P} 5-\mathrm{P} 6}=10.5$.

B : ${ }^{31} \mathrm{P}\left\{{ }^{1} \mathrm{H}\right\}$ NMR $\left(101.26 \mathrm{MHz}, \mathrm{Tol}, \mathrm{C}_{6} \mathrm{D}_{6}, 25{ }^{\circ} \mathrm{C},\right) \delta=64.0(\mathrm{dddd}, \mathrm{P} 1) ; 12.1(\mathrm{dd} \mathrm{P} 2)$, -8.7 (ddddd, P3), -126.2 (ddddd, P4), -157.7 (dddd, P5), -182.1 (dddd, P6), $\mathrm{J}_{\mathrm{P} 1-\mathrm{P} 2}=3.9, \mathrm{~J}_{\mathrm{P} 1-\mathrm{P} 3}=$ $28.4, \mathrm{~J}_{\mathrm{P} 1-\mathrm{P} 4}=85.0, \mathrm{~J}_{\mathrm{P} 1-\mathrm{P} 5}=162.3, \mathrm{~J}_{\mathrm{P} 1-\mathrm{P} 6}=196.9, \mathrm{~J}_{\mathrm{P} 2-\mathrm{P} 3}=283.3, \mathrm{~J}_{\mathrm{P} 2-\mathrm{P} 4}=32.8, \mathrm{~J}_{\mathrm{P} 2-\mathrm{P} 5}=2.2, \mathrm{~J}_{\mathrm{P} 2-\mathrm{P} 6}=$ $2.8, \mathrm{~J}_{\mathrm{P} 3-\mathrm{P} 4}=19.5, \mathrm{~J}_{\mathrm{P} 3-\mathrm{P} 5}=180.5, \mathrm{~J}_{\mathrm{P} 3-\mathrm{P} 6}=60.1, \mathrm{~J}_{\mathrm{P} 4-\mathrm{P} 5}=119.9, \mathrm{~J}_{\mathrm{P} 4-\mathrm{P} 6}=210.8, \mathrm{~J}_{\mathrm{P} 5-\mathrm{P} 6}=172.2[18]$. C : ${ }^{31} \mathrm{P}\left\{{ }^{1} \mathrm{H}\right\}$ NMR (161.94 MHz, THF, $\left.\mathrm{C}_{6} \mathrm{D}_{6}, 25{ }^{\circ} \mathrm{C},\right) \delta=49.6$ (dddd, P1); $13.2(\mathrm{dd} \mathrm{dP} 2)$, $8.3(\mathrm{ddd}, \mathrm{P} 3),-6.2(\mathrm{ddd}, \mathrm{P} 4),-38.9(\mathrm{ddd}, \mathrm{P} 5), \mathrm{J}_{\mathrm{P} 1-\mathrm{P} 2}=84.9, \mathrm{~J}_{\mathrm{P} 1-\mathrm{P} 3}=227.6, \mathrm{~J}_{\mathrm{P} 1-\mathrm{P} 4}=134.2, \mathrm{~J}_{\mathrm{P} 1-\mathrm{P} 5}=$ $289.1, \mathrm{~J}_{\mathrm{P} 2-\mathrm{P} 3}=16.0, \mathrm{~J}_{\mathrm{P} 2-\mathrm{P} 4}=256.8, \mathrm{~J}_{\mathrm{P} 3-\mathrm{P} 5}=13.8, \mathrm{~J}_{\mathrm{P} 4-\mathrm{P} 5}=193.8$,

Crystallographic refinement details. Diffraction data were recorded on a KUMA KM4 diffractometer with graphite-monochromated $\mathrm{Mo} \mathrm{K}_{\alpha}$ radiation using Sapphire-2 CCD detector (Oxford Diffraction Ltd). The apparatus was equipped with an open flow thermostat (Oxford Cryosystems) which enabled experiments at $120 \mathrm{~K}$. The structures were solved with direct methods and refined with the SHELX97 program package[30] with the full-matrix least-squares refinement based on $F^{2}$. The data were corrected for absorption with the CrysAlis RED program. All nonhydrogen atoms were refined anisotropically. All $\mathrm{H}$ atoms were positioned geometrically and refined using a riding model $\mathrm{C}-\mathrm{H}=0.95-0.99 \AA$ and $U_{i s o}(\mathrm{H})=1.2 U_{e q}(\mathrm{C})$ or $1.5 U_{e q}(\mathrm{C})$ for $\mathrm{CH}_{3}$ groups.

\section{Acknowledgements}

J.P. and R.G thank the Polish Ministry of Science and Higher Education (Grant Nr N N204 271535) for financial support.

\section{References}

[1] R. Waterman, Dalton Trans. 2009, 18

[2] H. Schäfer, Z. Anorg. Allg. Chem. 1979, 459, 129.

[3] H. Schäfer, Z. Naturforsch. 1979, 34B, 1358. 
[4] B. Deppisch, H. Schäfer, Z. Anorg. Allg. Chem. 1982, 490, 129.

[5] H. Schäfer, Acta Cryst. 1982, 38B, 748.

[6] H. Schäfer, D. Binder, Z. Anorg. Allg. Chem. 1987, 546, 55.

[7] H. Schäfer, D. Binder, D. Fenske, Angew. Chem. 1985, 97, 523; b) Angew. Chem. Int. Ed. $1985,24,522$.

[8] H. Schäfer, D. Binder, B. Deppisch, G. Mattern, Z. Anorg. Allg. Chem. 1987, 546, 79.

[9] R. A. Jones, A. L. Stuart, J. L. Atwood, W. E. Hunter, Organometallics 1983, 2, 874.

[10] M. Driess, H. Pritzkow, U. Winkler, J. Organomet. Chem., 1997, 529, 313

[11] R. Melenkivitz, D. J. Mindiola, G. L. Hillhouse, J. Am. Chem. Soc., 2002, 124, 3846

[12] R. Giannandrea, P. Mastrorilli, C.F. Nobile, U. Englert, J. Chem. Soc. Dalton, 1997, 1355

[13] U. Englert, E. Matern, J. Olkowska-Oetzel, J. Pikies. Acta Cryst. 2003, E59, m376

[14] M. A. Zhuravel, D. S. Glueck, L. N. Zakharov, A. L. Rheingold. Organometallics, 2002, 21, 3208

[15] H. Schäfer, D. Binder, Z. Anorg. Allg. Chem. 1988, 560, 65.

[16] P. Mastrorilli, C. F. Nobile, F. P. Fanizzi, M. Latronico, Chunhua Hu, U. Englert, Eur. J. Inorg. Chem., 2002, 1210.

[17] D. K. Wicht, S. N. Paisner, B. M. Lew, D. S. Glueck, G. P. A. Yap, L. M. Liable-Sands, A. L. Rheingold, C. M. Haar, S. P. Nolan, Organometallics, 1998, 17, 652.

[18] P. Mastrorilli, Eur. J. Inorg. Chem., 2008, 4835.

[19] W. Domańska-Babul, J. Chojnacki, E. Matern, J. Pikies, J. Organomet. Chem. 2007, 692, 3640 .

[20] W. Domańska-Babul, J. Chojnacki, E. Matern, J. Pikies, Dalton Trans. 2009, 146.

[21] E. Baum, E. Matern, A. Robaszkiewicz, J. Pikies, Z. Anorg. Allg. Chem. 2006, 632, 1073.

[22] I. Kovacs, H. Krautscheid, E. Matern, G. Fritz, J. Pikies, Z. Anorg. Allg. Chem. 1997, 623 1088.

[23] G. Fritz, E. Matern, H. Krautscheid, R. Ahlrichs, J. Olkowska, J. Pikies, Z. Anorg. Allg. Chem. 1999, 625, 1604. 
[24] E. Matern, J. Olkowska-Oetzel, J. Pikies, G. Fritz, Z. Anorg. Allg. Chem., 2001, 627, 1767.

[25] F. Basolo, Coord. Chem. Rev., 1996, 154, 151.

[26] R. G. Pearson, Inorg. Chem., 1973, 12, 712.

[27] H. Goesmann, E. Matern, J. Olkowska-Oetzel, J. Pikies, G. Fritz. Z. Anorg. Allg. Chem., 2001, 627, 1181.

[28] The NMR data and X-ray structure of $\mathrm{LiCl} \cdot 2\left\{\left(\mathrm{Et}_{2} \mathrm{~N}\right)_{2} \mathrm{P}-\mathrm{PLi}-\mathrm{P}^{\mathrm{t}} \mathrm{Bu}_{2}\right\} \cdot 2 \mathrm{THF}$ will be published elsewhere.

[29] B. K. Schmiedeskamp, J. G. Reising, W. Malisch, K. Hindahl, R. Schemm, W. S. Sheldrick, Organometallics, 1995, 14, 4446.

[30] T. G. Appleton, M. A. Benett, Inorg. Chem., 1978, 17, 738.

[31] G. M. Sheldrick, SHELX- 97. Programs for the solution and the refinement of crystal structures from diffraction data.

[32] CrysAlis RED, Oxford Diffraction Ltd., Version 1.171.29.9 (release 23-03-2006

CrysAlis171. NET) (compiled Mar 23 2006,23:39:28).

[33] ]. H. Krautscheid, E. Matern, G. Fritz, J. Pikies. Z. Anorg. Allg. Chem., 2000, 626, 253.

[34] G. Fritz, H. Goesmann, B. Mayer, Z. Anorg. Allg. Chem. 1992, 607, 26.

[35]. A. Wisniewska, K. Baranowska, J. Pikies, Acta Cryst. 2008, E64, m967.

[36] G. Schultz, N. Y. Subbotina, C. M. Jensen, J. A. Golen, J. Hargittai, Inorg. Chim. Acta 1992, $191,85$.

[37] T. A. Albright, R. Hoffmann, J. C. Thibeault, D. L. Thorn, J. Am. Chem. Soc. 1979, 101, 3801.

[38] a) S. Loss, C. Windauer, H. Grützmacher, Angew. Chem. 1999, 111, 3546; b) Angew. Chem. Int. Ed. 1999, 38, 3329.

[39] J. Chojnacki, A. Robaszkiewicz, E. Matern, E. Baum, J. Pikies, Acta Cryst. (2007) E63, m680-m683

[40] E. Matern, J. Pikies, G. Fritz, J. Pikies. Z. Anorg. Allg. Chem. 2000, 626, 2136.

[41] I. Kovacs, H. Krautscheid, E. Matern, E. Sattler, G. Fritz, W. Hönle, H. Borrmann, H.G. von Schnering, Z. Anorg. Allg. Chem. 1996, 622, 1564. 
1

2

3

4

5

6

7

8

9

10

11

12

13

14

15

16

17

18

19

20

21

22

24

25

26

27

28

29

30

31

32

33

34

35

36

37

38

39

40

41

42

43

44

45

46

47

48

49

50

51

52

53

54

55

56

57

58

59

60

[42] G. Fritz, T. Vaahs, Z. Anorg. Allg. Chem. 1987, 552, 18.

[43] I. Kovacs, E. Matern, G. Fritz, Z. Anorg. Allg. Chem. 1996, 622, 935. 


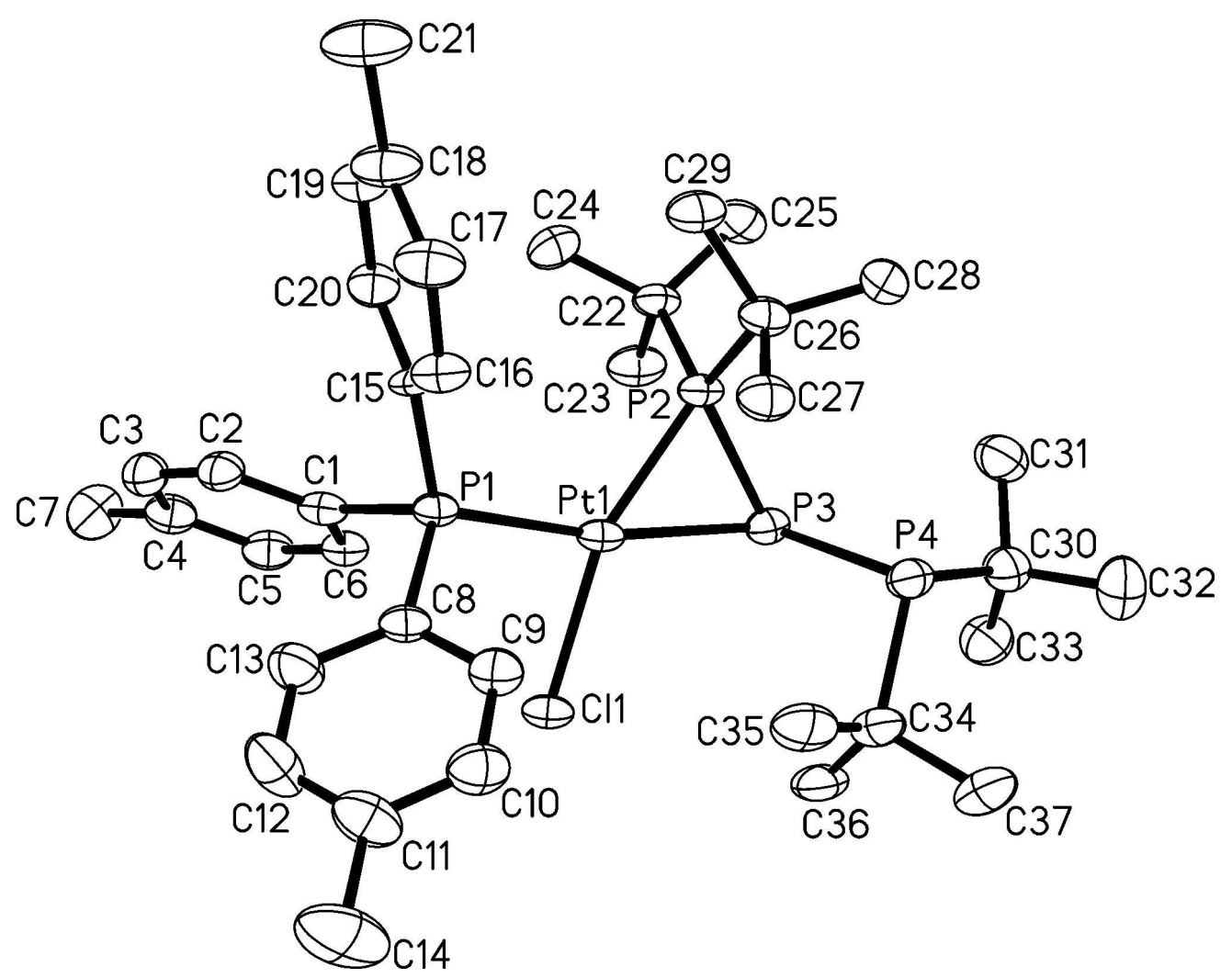

FIGURE 1. An ORTEP view of the molecular structure of $1 \mathrm{a}$ in the crystal; hydrogen atoms not shown, ellipsoids are drawn at $30 \%$ probability level. Selected bond lengths [pm] and angles $\left[^{\circ}\right.$ ]: Pt1-Cl1 236.37(15); Pt1-P1 228.53(17); Pt1-P2 221.24(16); Pt1-P3 240.77(18); P2-P3 214.50(2); P3-P4 221.80(3); P2-Pt1-P3 55.14(6); P2-P3-P4 106.92(10). $171 \times 136 \mathrm{~mm}(600 \times 600 \mathrm{DPI})$ 


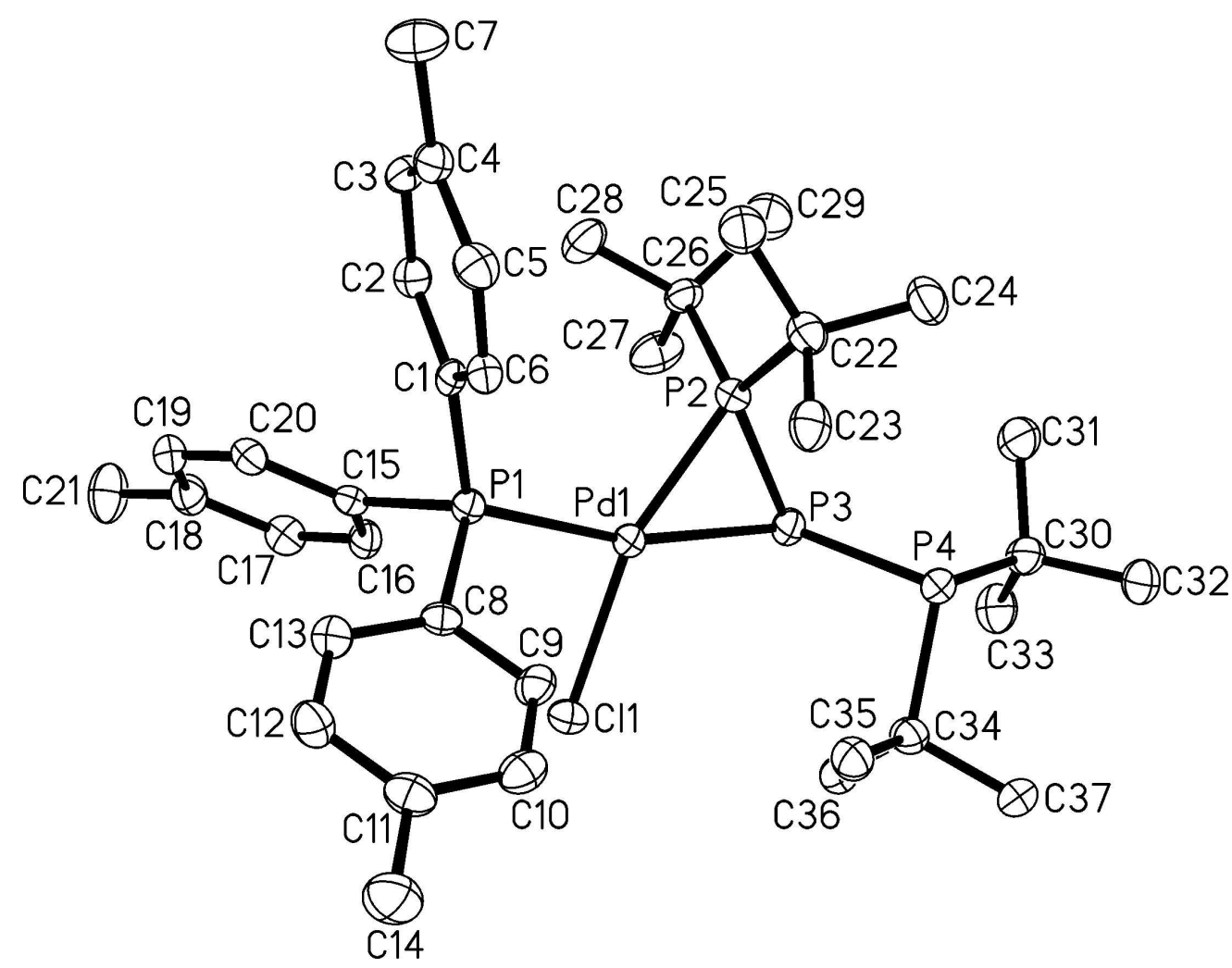

FIGURE 2. An ORTEP view of the molecular structure of $2 \mathrm{a}$ in the crystal; hydrogen atoms not shown, ellipsoids are drawn at 30\% probability level. Selected bond lengths [pm] and angles $\left[{ }^{\circ}\right]$ : Pd1-Cl1 238.62(9); Pd1-P1 234.32(9); Pd1-P2 223.15(9); Pd1-P3 241.79(9); P2-P3 213.03(13); P3-P4 222.40(13); P2-Pd1-P3 67.28(4); P2-P3-P4 106.78(5). $187 \times 145 \mathrm{~mm}(600 \times 600 \mathrm{DPI})$ 


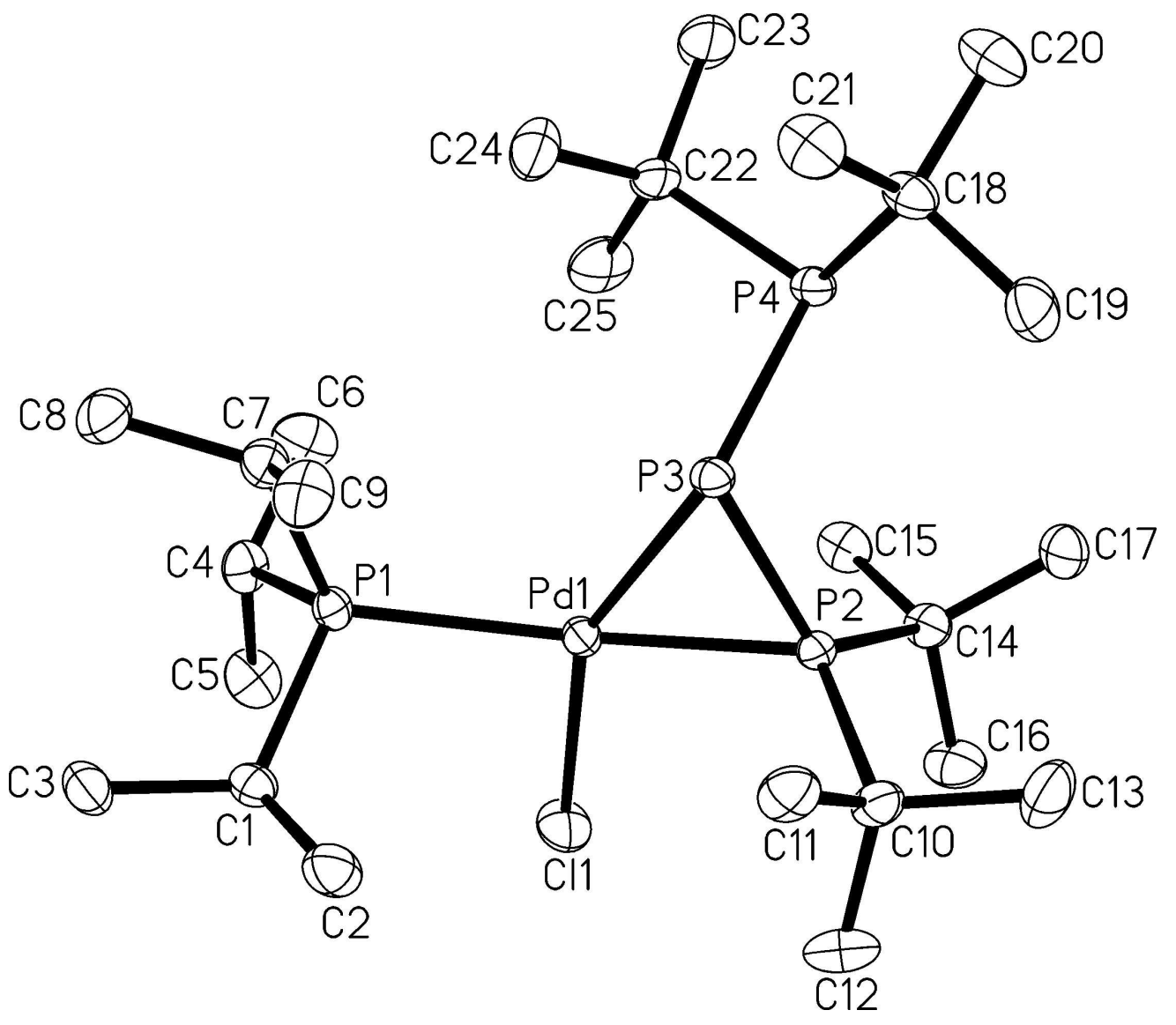

FIGURE 3. An ORTEP view of the molecular structure of $3 \mathrm{~b}$ in the crystal; hydrogen atoms not shown, ellipsoids are drawn at $30 \%$ probability level. Selected bond lengths [pm] and angles $\left[^{\circ}\right.$ ]: Pd1-Cl1 237.63(5); Pd1-P1 238.77(5); Pd1-P2 225.39(5); Pd1-P3 238.59(5); P2-P3 213.32(7); P3P4 224.05(7); P2-Pd1-P3 54.654(17); P2-P3-P4 102.96(3). $189 \times 164 \mathrm{~mm}(600 \times 600 \mathrm{DPI})$ 


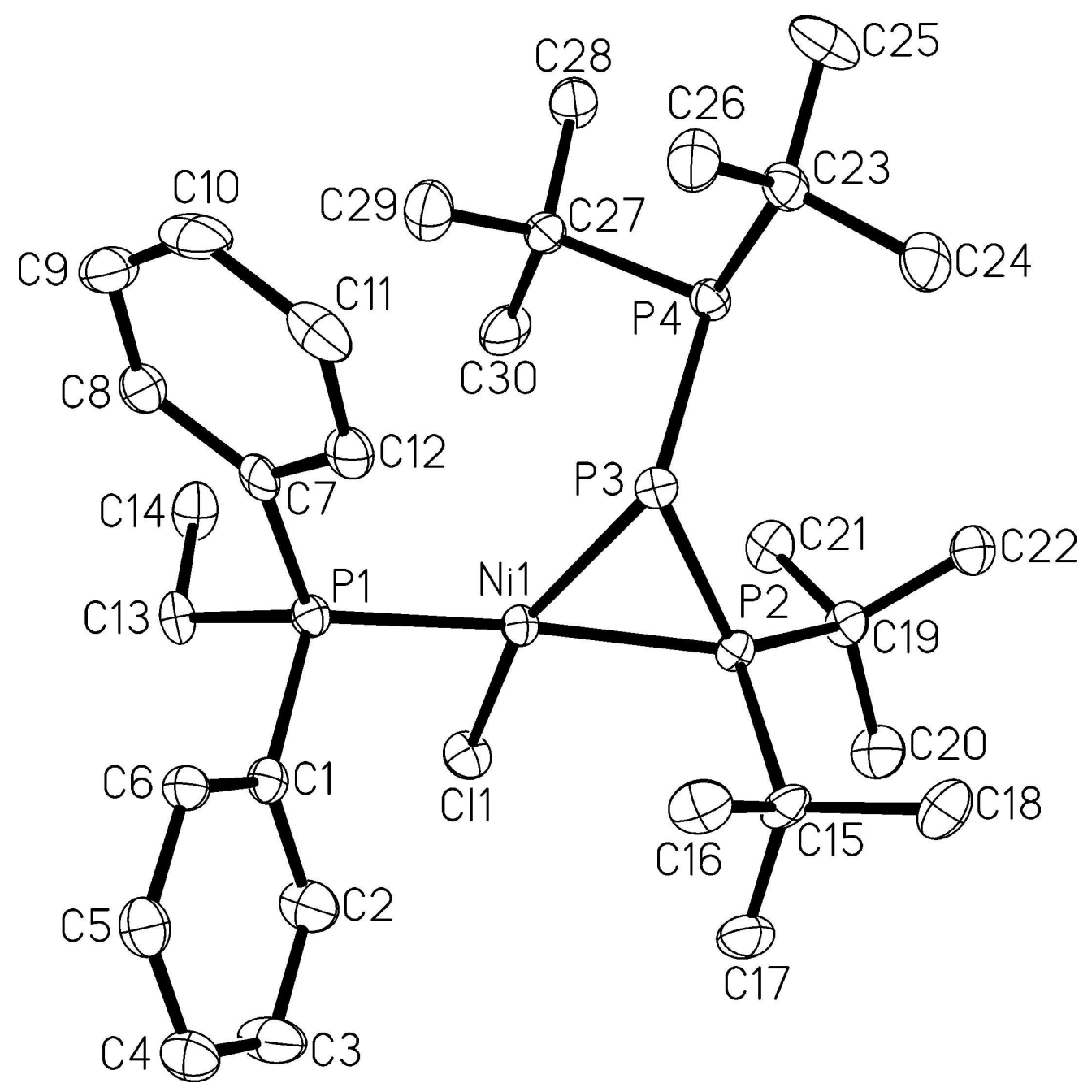

FIGURE 4. An ORTEP view of the molecular structure of $4 \mathrm{~b}$ in the crystal; hydrogen atoms not shown, ellipsoids are drawn at $30 \%$ probability level. Selected bond lengths [pm] and angles [ ${ }^{\circ}$ ]: Ni1-Cl1 220.46(9); Ni1-P1 223.68(10); Ni1-P2 214.83(10); Ni1-P3 226.05(10); P2-P3 212.54(12); P3-P4 224.80(12); P2-Ni1-P3 57.58(3); P2-P3-P4 105.58(5). $182 \times 184 \mathrm{~mm}(600 \times 600 \mathrm{DPI})$ 